\title{
Intermediate filament scaffolds fulfill mechanical, organizational, and signaling functions in the cytoplasm
}

\author{
Seyun Kim ${ }^{1}$ and Pierre A. Coulombe ${ }^{1,2,3}$ \\ ${ }^{1}$ Department of Biological Chemistry, The Johns Hopkins University School of Medicine, Baltimore, Maryland 21205, USA; \\ ${ }^{2}$ Department of Dermatology, The Johns Hopkins University School of Medicine, Baltimore, Maryland 21205, USA
}

Intermediate filaments (IFs) are cytoskeletal polymers whose protein constituents are encoded by a large family of differentially expressed genes. Owing in part to their properties and intracellular organization, IFs provide crucial structural support in the cytoplasm and nucleus, the perturbation of which causes cell and tissue fragility and accounts for a large number of genetic diseases in humans. A number of additional roles, nonmechanical in nature, have been recently uncovered for IF proteins. These include the regulation of key signaling pathways that control cell survival, cell growth, and vectorial processes including protein targeting in polarized cellular settings. As this discovery process continues to unfold, a rationale for the large size of this family and the contextdependent regulation of its members is finally emerging.

Intermediate filaments (IFs), first described by Holtzer and colleagues (Ishikawa et al. 1968) from studies of muscle in the late 1960s, serve as ubiquitous cytoskeletal scaffolds in both the nucleus and cytoplasm of higher metazoans (Erber et al. 1998). In human, mouse, and other mammalian genomes, $\sim 70$ conserved genes encode proteins that can self-assemble into 10- to $12-\mathrm{nm}$ wide IFs. Apart from three lamin-encoding genes, whose products localize to and function in the nucleus, the other $\sim 67$ IF genes encode cytoplasmic proteins (Table 1; Hesse et al. 2001). Although heterogeneous in size, primary structure, and regulation, IF proteins share a common tripartite domain structure, with the defining feature being a centrally located, 310-residue-long $\alpha$-helical domain (352 for lamins) containing long-range heptad repeats of hydrophobic/apolar residues (Fig. 1A). These conserved features were formalized with the cloning and sequencing of the first IF protein-encoding gene, keratin 14 (Hanukoglu and Fuchs 1982). The central "rod" domain mediates coiled-coil dimer formation and other-

[Keywords: Keratin; vimentin; cytoskeleton; adhesion; cell polarity; intracellular transport]

${ }^{3}$ Corresponding author.

E-MAIL coulombe@jhmi.edu; FAX (410) 614-7567.

Article is online at http://www.genesdev.org/cgi/doi/10.1101/gad.1552107. wise represents the major driving force sustaining selfassembly (for review, see Fuchs and Weber 1994; Herrmann and Aebi 2004; Parry 2005). The rod is flanked, at both ends, by nonhelical sequences that differ in length, sequence, substructure, and properties. Variations in the so-called "head" and "tail" domains account for the marked heterogeneity in IF protein size $\left(M_{r} \sim 40-240\right.$ $\mathrm{kDa})$ (Table 1) and other attributes. A "one gene/one protein" rule seems to prevail in the family, as relatively few IF mRNAs (lamin A/C, GFAP, peripherin, and synemin) (Table 1) yield distinct protein products via alternative splicing.

Most biomedical researchers' understanding of fibrous cytoskeletal polymers is primarily influenced by the extraordinary properties of F-actin and microtubules, whose pleiotropic roles tend to be universal and can be investigated in cultured cell lines and simple model eukaryotes (Alberts et al. 2002). IFs are fundamentally different, as follows: Functionally, cytoplasmic IF proteins are not required for life at the single-cell level, as evidenced by their complete absence in yeast, in Drosophila (Erber et al. 1998), and in some mammalian cell lines (Venetianer et al. 1983). Yet, they are clearly functionally required in a broad range of metazoans ranging from Caenorhabditis elegans (e.g., see Karabinos et al. 2001) to mammals (Fuchs and Cleveland 1998; Omary et al. 2004; this review), and possibly in bacteria as well (Ausmees et al. 2003). Biochemically, they exhibit an apolar (i.e., the two ends of the fiber are structurally identical) and heterogeneous substructure (Aebi et al. 1988; Herrmann and Aebi 2004). Whereas polymerized IFs exhibit cycles of disassembly and reassembly under "steady-state conditions" in vivo (e.g., see Vikstrom et al. 1992; Windoffer et al. 2004; for review, see Helfand et al. 2004), IF proteins do not directly bind and metabolize nucleotides as actin and tubulin do. Several IF proteins assemble into IFs as obligate heteropolymers (e.g., keratin, neurofilaments, nestin), while others (e.g., vimentin, desmin) can do so either as homo- or hetero-polymers. There currently are no data consistent with IFs serving as "tracks" for molecular motors, yet they significantly contribute to the complex cytoarchitecture of a host of differentiated cell 
Table 1. IF proteins

\begin{tabular}{|c|c|c|c|c|}
\hline IF name & Type & $\begin{array}{l}\text { Size } \\
(\mathrm{kDa})\end{array}$ & Cell and tissue distribution & Key feature and/or disease association \\
\hline \multicolumn{5}{|l|}{ Cytoplasmic } \\
\hline Keratins $^{\mathrm{a}}$ & $\mathrm{I}(n=28)$ & $40-64$ & $\begin{array}{l}\text { K9-K28 (epithelia); } \\
\text { K31-K40 (hair/nail) }\end{array}$ & \multirow{2}{*}{$\begin{array}{l}\text { Types I and II keratins form obligate } 1: 1 \text { heteropolymers. } \\
\text { There are } 54 \text { functional keratin genes in } \\
\text { the human genome. } \\
\text { Mutated in }>20 \text { diseases. }\end{array}$} \\
\hline Keratins $^{\mathrm{a}}$ & $\mathrm{II}(n=26)$ & $52-68$ & $\begin{array}{l}\text { K1-K8, K71-K74 (epithelia); } \\
\text { K81-K86 (hair). }\end{array}$ & \\
\hline Vimentin & III & 55 & Mesenchymal & Widely expressed in embryos. \\
\hline Desmin & III & 53 & Muscle & Mutated in cardiomyopathies. \\
\hline GFAP & III & 52 & Astrocytes/glia & Mutated in Alexander disease. \\
\hline Peripherin & III & 54 & Peripheral neurons & Induced after neuronal injury. \\
\hline $\begin{array}{l}\text { Neurofilaments } \\
\text { (L,M,H chains })\end{array}$ & IV & $61-110$ & CNS neurons & $\begin{array}{l}\text { NF- } L, M \text {, and } H \text { form obligatorily heteropolymers } \\
\text { with } \alpha \text {-internexin. }\end{array}$ \\
\hline$\alpha$-Internexin & IV & 66 & CNS neurons & Neuronal IFs are key effectors of axonal radial growth. \\
\hline Nestin & IV & 177 & Neuroepithelial & Markers of "early" progenitor (stem) cells in several tissues. \\
\hline Syncoilin & IV & 54 & Muscle & Interacts with $\alpha$-dystrobrevin. \\
\hline Synemin & IV & 182 & Muscle & $\begin{array}{l}\alpha \text { and } \beta \text { isoforms; } \beta \text { form is also known as desmuslin; } \\
\text { binds actin-associated proteins. }\end{array}$ \\
\hline \multicolumn{5}{|l|}{ Nuclear } \\
\hline Lamins B1, B2 & $\mathrm{V}$ & $66-68$ & Nuclear lamina & Enriched in progenitor cells. \\
\hline Lamins A/C & $\mathrm{V}$ & $62-78$ & Nuclear lamina & $\begin{array}{l}\text { Subject to differential splicing; enriched } \\
\text { in differentiated cells. Mutated in a } \\
\text { progeria condition, muscular dystrophy, and others. }\end{array}$ \\
\hline \multicolumn{5}{|l|}{ Orphan } \\
\hline Phakinin (CP49) & undefined & 47 & Lens & \multirow{2}{*}{$\begin{array}{l}\text { CP49 and filensin form beaded filaments in lens epithelial } \\
\text { cells. CP49 mutations cause cataracts. }\end{array}$} \\
\hline Filensin & undefined & 83 & Lens & \\
\hline
\end{tabular}

${ }^{a}$ The keratin nomenclature has recently been revised (see Schweizer et al. 2006).

types. This text discusses the recent inroads made toward defining the properties and functions of cytoplasmic IFs, and identifies some of the key challenges lying ahead. Concurrent progress made for the nuclear lamins is not discussed but was recently covered by others (Gruenbaum et al. 2005; Worman and Courvalin 2005; Broers et al. 2006; Capell and Collins 2006; Mattout et al. 2006; Navarro et al. 2006).

\section{General features of IFs}

\section{Structure}

Form defines function. For cytoskeletal polymers, "form" consists of the combination of their structure and functional organization, including assembly sites, dynamics and turnover, and integration with other elements of the cell. Owing to the presence of longrange heptad repeats (Fig. 1A), cytoplasmic IF proteins readily form highly stable coiled-coil dimers (42-44 nm in length) in which the two participating monomers exhibit a parallel, in-register alignment. Dimers then associate along their lateral surfaces, with an antiparallel orientation, to form apolar tetramers (Fig. 1B), which are readily obtained in high yield in vitro and have been isolated as soluble entities from in vivo sources (Soellner et al. 1985; Herrmann and Aebi 2004; Bernot et al. 2005). IF proteins have been difficult to crystallize, owing to their notorious insolubility, lack of suitable assembly inhibitors, and polymerization-prone charac- ter (Strelkov et al. 2001), and thus there is as yet no "atomic-level" information for the structure of polymerized IFs. Various analyses of filaments, both in vitro (Aebi et al. 1988; Herrmann and Aebi 2004) and in suitable tissues in vivo (e.g., see Er Rafik et al. 2004; Norlen and Al-Amoudi 2004), have shown that mature IFs (Fig. 1C) are comprised of several subfibrils (Fig. 1D). The presence of a clear 21- to 22-nm axial repeat in some EM preparations of filaments (Aebi et al. 1983, 1988) implies that coiled-coiled dimers are staggered in a consistent fashion within the wall of the mature polymer. How subunits interact, laterally and longitudinally, to give rise to mature IFs is being defined with increasing depth (e.g.,see Hess et al. 2004; Bernot et al. 2005; Sokolova et al. 2006). Compared with the central rod, the contributions of the $\mathrm{N}$-terminal head and C-terminal tail domains to filament assembly vary depending on the IF protein considered. Given their exposure at the polymer surface, the end domains are poised to mediate interactions with other filaments and a host of cellular proteins, as well as serve as substrates for posttranslational modifications that regulate structure, organization, and function /Coulombe and Wong 2004; Green et al. 2005; Izawa and Inagaki 2006; Omary et al. 2006).

\section{Organization within the cell}

IFs are integrated with other key elements making up the cell's interior. They interact with the other major 
A

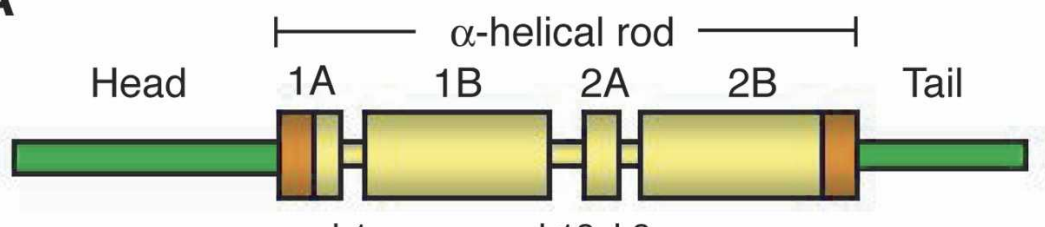

L1

L12 L2

B

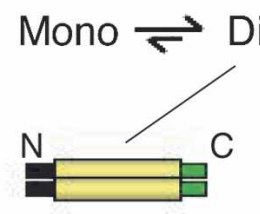

Polar
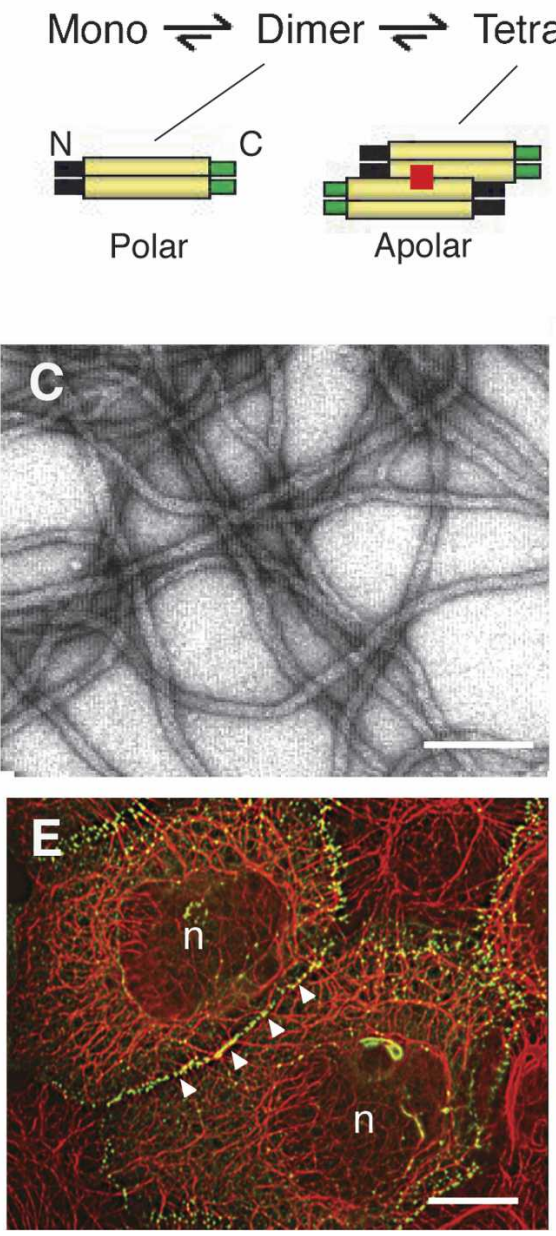
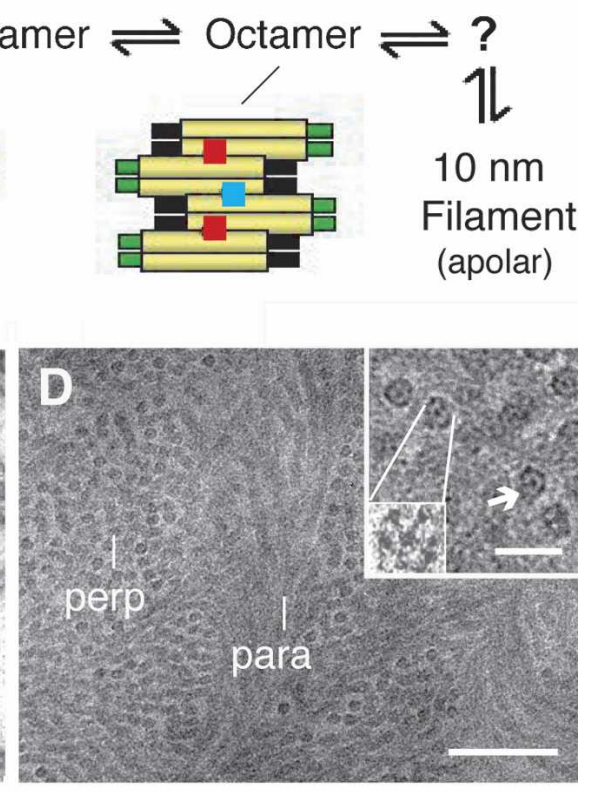

(apolar)
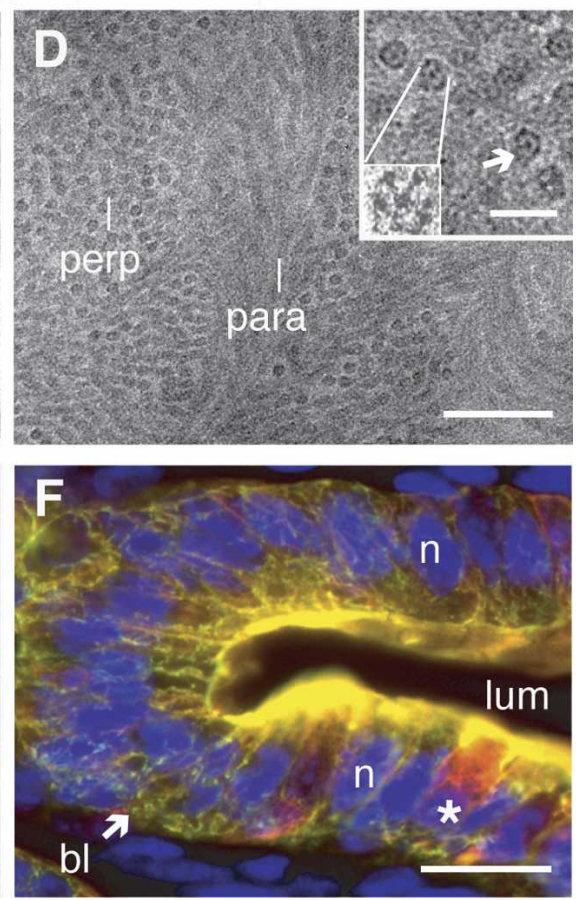

Figure 1. Introduction to cytoplasmic IFs. (A) Schematic representation of the tripartite domain structure shared by all keratin and other IF proteins. A central $\alpha$-helical "rod" domain acts as the major determinant of self-assembly and is flanked by nonhelical "head" and "tail" domains at the $\mathrm{N}$ and $\mathrm{C}$ termini, respectively. Within this 310 -amino-acid-long rod domain, the heptad repeat-containing segments $1 \mathrm{~A}, 1 \mathrm{~B}$, $2 \mathrm{~A}$, and $2 \mathrm{~B}$ are interrupted at three conserved locations by linker sequences L1, L12, and L2. Rod domain boundaries consist of highly conserved 15- to 20-aminoacid regions (shown in orange) that are crucial for polymerization and are frequently mutated in human disease (see http://www. interfil.org). (B) Assembly pathways for cytoplasmic IF proteins. A detailed account is provided in the text. Of particular importance, the coiled-coil dimers are structurally polar owing to the parallel and in-register orientation of the participating monomers, whereas the tetramer is structurally apolar owing to the anti-parallel orientation of coiled-coil dimers. The mature $\sim 10-\mathrm{nm}$ fiber is apolar as well. The red dot denotes axial overlap of subdomain 1B, while the blue dot depicts subdomain $2 \mathrm{~B}$ overlap (see $A$ ). The nature of a possible intermediate beyond octamer formation is unclear (see "?"); in vitro, formation of a "unit-length filament" is seen for specific IF proteins. $(C)$ Visualization of filaments, reconstituted in vitro from purified human $\mathrm{K} 5$ and K14 proteins, by negative staining and electron microscopy. Bar, $100 \mathrm{~nm}$. (D) Visualization of native keratin IFs in the stratum corneum layer of human epidermis using cryotransmission electron microscopy on a fully hydrated, vitreous tissue specimen (Norlen and Al-Amoudi 2004). Bundles of tightly packed keratin IFs run parallel (para) or perpendicular (perp) to the sectioning plane. Bar, $50 \mathrm{~nm}$. (Inset) Detailed views of filaments in cross-section, shown at two magnifications. As many as seven subfibrils, including a centrally located one, can be seen. Bar, $20 \mathrm{~nm}$. Courtesy of Dr. Lars Norlen. (E) Skin epidermal keratinocytes in culture. Dual immunofluorescence labeling for keratin (red chromophore) and desmoplakin, a desmosome component (green chromophore). Keratin IFs are organized in a network that spans the whole cytoplasm, and are attached to desmosomes at points of cell-cell contacts. (n) Nucleus. Bar, $20 \mu \mathrm{m}$. Courtesy of Dr. Kathleen Green. (F) Gut epithelial wall in cross-section, emphasizing the epithelium. This fresh frozen specimen was triple-labeled for K8/K18 (red chromophore), K19 (green chromophore), and nuclei (blue chromophore). Note the concentration of staining at the apical pole of enterocytes. The asterisk denotes a goblet cell, which also features a prominent K8/K18 network in the cytoplasm. (bl) Basal lamina; (lum) lumen; (n) nucleus. Bar, $20 \mu \mathrm{m}$. Courtesy of Dr. Diana Toivola.

determinants of cellular architecture, including microtubules, F-actin, and various types of adhesive complexes spanning the outer cell membrane, including desmosomal (cell-cell) attachments and integrin-based linkages to the extracellular matrix (Svitkina et al. 1996; Fuchs and Cleveland 1998; Jefferson et al. 2004). Proteins of the plakin family serve as ideal molecular bridges mediating many of these attachments. Thus desmoplakin, plectin, BPAG isoforms, to name a few, are unusually large and feature a modular substructure that consists of a long coiled-coil forming, $\alpha$-helical rod domain in their center, flanked by globular domains that house the determinants mediating binding to IFs and other cytoskeletal proteins (Fuchs and Cleveland 1998; Wiche 1998; Jefferson et al. 2004). Disrupting the function of plakin proteins in vivo yields clinically significant phenotypes (see Jefferson et al. 2004; Omary et al. 2004) that overlap with genetic deficiencies in relevant cytoplasmic IF 
genes (as detailed below). IFs also interact with organelles, including mitochondria, Golgi, endosomes, and lysosomes (for review, see Toivola et al. 2005) in the cytoplasm and are anchored at the surface of the nucleus. A long-awaited development recently took place as Wilhelmsen et al. (2005) provided evidence that nuclear attachment of cytoplasmic IFs occurs via plectin-mediated interaction with nesprin-3, a new protein that spans the nuclear envelope. Further studies are needed to ascertain the role of nesprin-3-mediated attachments in living tissues and organs and investigate whether this nuclear anchoring mechanism is of widespread relevance.

In vivo, the architecture of the cytoplasmic IF network varies according to cell type and tissue context. In skin keratinocytes, for instance, keratin IFs form a dense, pan-cytoplasmic network that is anchored at points of cell-matrix and cell-cell adhesion (Fig. 1E), whereas in polarized (simple) epithelial linings, they are sparser and often concentrated near the apical pole of the cell (Fig. $1 F$; Coulombe and Omary 2002). A similar situation prevails in differentiated myofibers, where desmin IFs are concentrated at the Z-lines linking adjacent sarcomeres (Lazarides 1980). In fibroblasts, IFs extend through much of the cytoplasm, often in close juxtaposition to microtubules (Ball and Singer 1981). A striking example of differentiation-dependent organization of cytoplasmic IFs is found in myelinated neurons of the CNS. Neurofilaments, which are heteropolymers of " $\mathrm{L}$," " $\mathrm{M}$," and " $\mathrm{H}$ " subunits in an 5:3:1 molar ratio (a notion that may need revision in light of recent data) (see Yuan et al. 2006), are highly abundant in the axoplasm, where they run in parallel arrays and markedly outnumber microtubules. In this setting, neurofilaments are required for the radial growth of axons, a major determinant of conduction velocity (Cleveland et al. 1991). When visualized by electron microscopy, neurofilaments exhibit side arms that project laterally, at regular intervals, from the 10- to 12 nm filament core (Hirokawa et al. 1984). These side arms represent the unusually long C-terminal tail domains of the NF-M and NF-H subunits; they feature KSP repeats that are nearly stoichiometrically phosphorylated in vivo, potentially accounting for their orientation nearly perpendicular to the filament core (Lariviere and Julien 2004). An elegant set of studies recently revealed that it is the tail domain of NF-M (Garcia et al. 2003), not NF-H (Rao et al. 2002b), that is targeted by the myelin-directed, "outside-in" signal(s) responsible for the phosphorylation-dependent radial growth of myelinated axons. These sidearms also contribute to regulating the axonal transport of NF proteins (for review, see Lariviere and Julien 2004).

Of note, additional IF proteins (e.g., synemin, nestin) (see Table 1) display exceptionally long "tail domains" at their $\mathrm{C}$ termini. In the case of synemin, binding determinants located within this large tail domain account for its ability to interact with Z-lines and costameres in myocytes (Bellin et al. 2001) as well as components of focal adhesions in hepatic stellate cells (Uyama et al. 2006). By contrast K19, a type I keratin (Table 1), has an exceedingly short tail domain, and this character partly dictates the "stickiness" of the filaments it forms with its type II partner K5 (Bousquet et al. 2001). Other than as substrates for post-translational modifications, the "end domains" thus participate in IF organization in vivo through interactions with cis- and trans-acting (protein) determinants.

\section{Assembly, dynamics, and turnover}

Control over polymerization provides a key point of regulation for the organization and function of cytoskeletal filaments. There is, as yet, no defined "nucleator"i.e., an Arp2/3- or $\gamma$-tubulin-containing equivalent (Alberts et al. 2002)—for cytoplasmic IFs. There is evidence, from studies of cultured cells, that keratin proteins are synthesized and assembled in the peripheral cytoplasm (Windoffer et al. 2004), near actin-rich focal contacts (Windoffer et al. 2006). Alternatively, some IF proteins like the type III peripherin undergo microtubule-dependent, cotranslational assembly (Chang et al. 2006; see also Isaacs et al. 1989). There also is emerging evidence for temporal control as well. Neurofilament subunits are translated in the cell body, and transported down the axon as assembly subunits (via the "fast transport" pathway) or filament polymers (via the "slow" pathway) (e.g., see Yan and Brown 2005). In early-stage mouse embryos (8- to 16-cell stage), type II keratins are translated significantly ahead of their type I assembly partners and temporarily stored unpolymerized in small aggregates (Lu et al. 2005).

Once synthesized, IF proteins tend to be very stable, exhibiting long half-lives, though they can be turned over rapidly by the proteasome in a phosphorylation- and ubiquitin-dependent fashion (e.g., see $\mathrm{Ku}$ and Omary 2000). Mice null for Mrj protein, a cochaperone protein to which K8/K18 bind (Izawa et al. 2000), die in utero correlating with the presence of keratin aggregates in chorionic trophoblast cells, believed to interfere with chorioallantoic attachment during placental development (Watson et al. 2007). The available data show that Mrj is required for the proteasome-mediated degradation of $\mathrm{K} 8 / \mathrm{K} 18$ in that context (Watson et al. 2007). Assembled IFs, on the other hand, can be quite dynamic depending, again, on context (Helfand et al. 2004). The mechanism(s) responsible for steady-state dynamics of IFs remain to be defined; it does not involve the metabolism of a subunit-bound nucleotide. The small nematode major sperm protein (MSP; $14 \mathrm{kDa}$ ) may be inspirational in that regard: It forms long and apolar filaments that exhibit an actin-like treadmilling-like behavior at the leading edge of locomoting sperm cells (déjà vu!). MSP filament dynamics requires ATP (although MSP protein itself does not bind nucleotides), a membrane phosphoprotein and at least two cytoplasmic proteins (Stewart and Roberts 2005), and the combined action of these proteins presumably fosters MSP subunit loss from the polymer. Back to IFs, another key unsolved issue about their steady-state dynamics is whether subunit exchange occurs at filament ends, as is true for MSP (Stewart and 
Roberts 2005), actin, and mirotubules (Alberts et al. 2002), or within the IF core, as suggested (Vikstrom et al. 1992).

\section{Tissue- and context-dependent regulation of IF genes}

A truly remarkable aspect of IF genes is their tight, differentiation-related regulation. As a general principle, distinct IF genes are transcribed as cells initially develop, mature, and reach the final differentiation state. As part of normal tissue homeostasis (e.g., repair following injury) and in disease states, mature cell types often revert to a developmental-like pattern of IF gene expression. The tight, context-dependent regulation of IF genes has been largely conserved, especially among mammals, as have the primary structure of their protein products, casting IF proteins as determinants of "tissue specificity." Other than its functional implications, the contextdependent transcription of IF genes provides an obvious and exceptional vantage point from which to define the molecular mechanisms responsible for differentiation and its plasticity. The main features of IF proteins are summarized in Table 2.

\section{Cytoplasmic IFs and mechanical support: a matter of integrity}

Experimental mutagenesis studies (e.g., see Albers and Fuchs 1987; Coulombe et al. 1990; Hatzfeld and Weber 1991) established early on that altering the sequence of the rod domain (Fig. 1A) can profoundly and dominantly alter IF assembly in vitro and in vivo. This set the stage for studies in which various K14 rod domain mutants were tissue-specifically expressed, at substoichiometric levels, in transgenic mice (Coulombe et al. 1991b; Vassar et al. 1991). These mice exhibited trauma-induced skin blistering associated with K14-mutant induced disruption of keratin filament network architecture in the relevant subset of epidermal keratinocytes. Other than highlighting the functional importance of keratin filaments in vivo, this blistering phenotype correctly hinted at the genetic basis for a phenotypically similar human condition, epidermolysis bullosa simplex (EBS) (Bonifas et al. 1991; Coulombe et al. 1991a; Lane et al. 1992). Additional studies confirmed that the cell fragility seen in EBS corresponds to a loss-of-function phenotype. Key among them were the severe epithelial blistering phenotype exhibited by K14- and K5-null mice (Lloyd et al. 1995; Peters et al. 2001), the finding that disease-causing mutations in either K5 or K14 markedly weaken the mechanical resilience of $\mathrm{K} 5-\mathrm{K} 14$ filament assemblies in vitro (Ma et al. 2001; Gu and Coulombe 2005) and affect de novo IF network formation in live keratinocytes (Werner et al. 2004), and the realization that EBS disease severity correlates with the impact of K5 or K14 mutations on IF assembly in vitro (e.g., see Letai et al. 1993).

EBS rapidly evolved into a paradigm (e.g., see Fuchs and Coulombe 1992), and we now know of $>40$ genetically determined diseases having, as their root cause, a mutation in an IF-encoding gene (Fuchs and Cleveland 1998; Irvine and McLean 1999; Omary et al. 2004; see http://www.interfil.org). Collectively, these disorders span a very broad clinical range that includes ectodermal dysplasias, myopathies and cardiomyopathies, neuropathies, lipodystrophies, and premature aging. In many instances, the disease is caused by a small mutation (missense allele; small insertion or deletion) (http://www. interfil.org) behaving dominantly, and its pathogenesis often involves fragility of the mutant IF protein-expressing cell type(s) (Fuchs and Cleveland 1998; Porter and Lane 2003; Omary et al. 2004). Along with studies of null and transgenic mouse models, characterization of these diseases established that all types of IF proteins (Table 1) are engaged in a role of structural support in vivo. For a significant number of IF-based disorders, clinical symptoms and underlying pathology also point to cellular defects of a nonmechanical nature. As an example, several IF-associated diseases (or phenotypes in mice) are typified by the presence of intracellular aggregates of unpolymerized IF proteins that prove toxic to the cell (for discussions, see Omary et al. 2004; Zatloukal et al. 2004; Watson et al. 2007).

Efforts are increasingly being devoted to defining the mechanical properties of IF-rich cells and tissues (Henrion et al. 1997; Helmke et al. 2000; Brown et al. 2001; Beil et al. 2003; Er Rafik et al. 2004; Suresh et al. 2005), those of individual IFs (Guzman et al. 2006; Kiss et al. 2006), and how these properties might be regulated during stress (e.g., see Perng et al. 1999; Helmke et al. 2000; Ridge et al. 2005). As expected, the ability to provide structural support requires that IFs be organized into a "network" that integrates them with actin, microtubules, various types of adhesion complexes, and the nucleus (e.g., see Lammerding et al. 2004), and the regulation of which involves interactions with "noncytoskeletal" proteins (e.g., kinases, phosphatases, heat-shock proteins, etc.). There are examples of "phenotypic convergence" reflecting this interdependency. Plectin deficiency causes a form of EBS with muscular dystrophy (McLean et al. 1996; Smith et al. 1996; Andra et al. 1997); EBS is otherwise a keratin-based disease, as already discussed, while a different form of muscular dystrophy is caused by mutations in lamin A/C (Bonne et al. 1999). Perhaps more compelling, type 2 Charcot-Marie-Tooth disease can be caused by mutations in either NF-L (Mersiyanova et al. 2000; De Jonghe et al. 2001), lamin A/C (De Sandre-Giovannoli et al. 2002), or the small heatshock protein hsp27 (Evgrafov et al. 2004), which binds IFs in vivo (e.g., see Perng et al. 1999). Likewise, the same type of myopathy can be caused by mutations in either desmin (Goldfarb et al. 1998; Muñoz-Mármol et al. 1998) or $\alpha$ B-crystallin (Vicart et al. 1998), another small heatshock protein that binds IFs in vivo (Wisniewski and Goldman 1998; Perng et al. 1999). A better understanding of the mechanisms and interactions underlying IFs' contribution to structural support may lead to the design of alternative therapeutic strategies for IF-based diseases, which are largely nonexistent at present (Omary et al. 2004). 
Table 2. Main features of IFs

\begin{tabular}{|c|c|}
\hline Description & Comment \\
\hline Large multigene family & $\begin{array}{l}\text { Approximately } 70 \text { genes; one of the large gene families occurring in } \\
\text { mammalian genomes. }\end{array}$ \\
\hline Late appearance during evolution ${ }^{a}$ & $\begin{array}{l}\text { Lamins excepted, IFs are mostly restricted to metazoans lacking a hard } \\
\text { exoskeleton. }\end{array}$ \\
\hline Context-dependent regulation & $\begin{array}{l}\text { IF gene transcriptional regulation is dynamic, and related to cell-type and } \\
\text { differentiation program. IF proteins are subject to dynamic } \\
\text { phosphorylation and other modifications. }\end{array}$ \\
\hline A conserved central "rod" domain & $\begin{array}{l}\text { This domain, } 310 \text { and } 352 \text { residues long in (most) cytoplasmic and nuclear } \\
\text { IF proteins, respectively, features long-range heptad repeats that foster the } \\
\text { formation of elongated, } 42 \text { - to } 44 \text {-nm-long coiled-coil dimers, and also } \\
\text { drive subsequent stages of polymerization. }\end{array}$ \\
\hline $\begin{array}{l}\text { A complex assembly pathway yields } \\
\text { apolar 10- to } 12 \text {-nm filaments }\end{array}$ & $\begin{array}{l}\text { Mature filaments are structurally apolar because of the anti-parallel } \\
\text { orientation of constituent coiled-coil dimers. In vivo, most IFs are } \\
\text { heteropolymers (obligatory or facultative). There is structural } \\
\text { heterogeneity between types of IF polymers. Variable surface chemistry } \\
\text { promotes interaction with various partners, and likely promotes diversity } \\
\text { of function as well. }\end{array}$ \\
\hline Dynamic properties and organization & $\begin{array}{l}\text { IF proteins do not bind or metabolize nucleotides, yet assembled IFs can be } \\
\text { very dynamic within the cell. IFs are attached at the nucleus and at } \\
\text { adhesion sites, and are otherwise integrated with F-actin and microtubules } \\
\text { in the cytoplasm. Plakin family proteins play a key role in those } \\
\text { attachments. }\end{array}$ \\
\hline Association with diseases $(n>40)$ & $\begin{array}{l}\text { Usually involves dominantly acting mutations (mostly missense alleles). } \\
\text { These diseases are individually rare. Disease pathogenesis often involves } \\
\text { cell fragility. }\end{array}$ \\
\hline
\end{tabular}

They may be present in some bacteria.

\section{IFs participate in the regulation of tissue growth and regeneration}

\section{Keratins regulate the translational apparatus}

Tissue injury rapidly elicits a multifaceted repair program that involves the activation of wound-proximal resident cells and their participation in wound-site restoration. In many tissues (skin, liver, CNS, muscle, etc.), profound changes in the transcription and/or post-transcriptional regulation of IF genes and proteins are seen in wound-proximal cells (DePianto and Coulombe 2004). In part, the resulting alterations in the composition and organization of the IF network likely alter cellular viscoelastic properties so as to optimize migration of regenerating cells into the wound (Coulombe and Wong 2004). In light of the large number of signaling proteins known to interact with IFs (e.g., see Omary et al. 2004; Green et al. 2005), these alterations may well fulfill additional purposes during tissue repair. Two studies in particular revealed nonmechanical roles for IF proteins in this setting (Perlson et al. 2005; Kim et al. 2006).

Like K6 and K16, K17 is a wound-inducible gene in the embryonic ectoderm and in adult skin (Mazzalupo et al. 2003). K17-null embryos exhibit a delay in the closure of surface wounds (Mazzalupo et al. 2003), which correlates with a failure of wound-proximal epithelial cells to undergo the expected large increase in size (Kim et al. 2006). K17-null skin keratinocytes are also smaller while in primary culture, where they reproducibly show an $\sim 18 \%$ depression in translation paralleled with reduced activity of Akt and mTOR kinases, selectively (Kim et al. 2006). A newly discovered interaction between K17

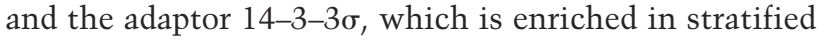
epithelia and is seemingly wound-inducible in skin, provided part of the explanation for this surprising phenotype (Kim et al. 2006). 14-3-3 proteins had been implicated by others as activators of protein synthesis since they somehow negate TSC1/TSC2's ability to negatively regulate mTOR (Bertram et al. 1998; Cai et al. 2006). Most likely, site-specific phosphorylation on the head domain of K17 creates a composite binding site for 14$3-3 \sigma$, causing its partial retention in the cytoplasm, where it can foster a full activation of mTOR in woundor serum-activated keratinocytes (Kim et al. 2006).

Does this newly defined function of K17 apply to other epithelial settings, and moreover, is it provided by other IF proteins in relevant settings? There are indications that such is the case. Suprabasal keratinocytes are markedly hypertrophied in the epidermis of K10-null mice, and this correlates with marked elevation in K17 and 14-3-3 $\sigma$ proteins (Reichelt and Magin 2002). K8-null hepatocytes also are smaller and show depressed protein synthesis while in culture, although the underlying mechanism is reportedly distinct from that occurring in K17-null keratinocytes (Galarneau et al. 2007). Vimentin (Tzivion et al. 2000), GFAP (Satoh et al. 2004), K18 (Liao and Omary 1996), and probably a score of other IF proteins, bind 14-3-3 in vivo. Consistent with the pleiotropic roles of 14-3-3 adaptor proteins in the cell, the significance of these interactions may vary depending on the 14-3-3 species involved and, of course, context. 
There is evidence that 14-3-3 binding regulates the assembly state and dynamics of K18-containing IFs (Liao and Omary 1996) and GFAP-containing IFs (Li et al. 2006), and the K18/14-3-3 interaction also influences cell cycle progression (see below). Finally, keratins or other IF proteins interact with other components of the translational apparatus, including, for instance, eEF1B $\gamma$ (Bousquet et al. 2001), eIF3 (Lin et al. 2001), TSC1 (Haddad et al. 2002), and even ribosomes (e.g., see Traub et al. 1998). A recent study found that the translation elongation factor eEF1B $\gamma$ interacts with, and promotes the bundling of, various types of keratin, but not vimentin, IFs; conversely, disruption of the keratin-eEF1B $\gamma$ interaction in vivo affects protein synthesis in a manner comparable with eEF1B $\gamma$ silencing (S. Kim, unpubl.).

More on keratin/14-3-3 interaction: a key to cell cycle entry?

Mitosis represents another key setting in which keratin phosphorylation is linked to an increased association with 14-3-3. Modest overexpression of a K18 site-directed mutant (Ser33 $\rightarrow$ Ala) unable to bind 14-3-3 elicits a limited mitotic arrest as well as abnormal mitotic figures in hepatocytes of regenerating adult mouse livers, correlating with altered keratin IF organization and aberrant localization of 14-3-3 in "nuclear speckles" (Ku et al. 2002). In a more recent study, Margolis et al. (2006) proposed that phosphorylated keratins provide a "14-3-3 sink" required to drive the entry of Xenopus egg extracts into mitosis. Their data suggest that activation of the phosphatase cdc25, an event required for mitotic entry, occurs only once the bound 14-3-3 has been "transferred" to a new partner, a niche for which keratins may be ideally suited, given their abundance and perceived neutrality during mitosis. The model devised by Margolis et al. (2006) could account for the liver regeneration phenotype reported by $\mathrm{Ku}$ et al. (2002) and is also appealing in light of the marked increase generally seen in IF protein phosphorylation during the course of mitosis (for review, see Izawa and Inagaki 2006; Omary et al. 2006). It also supports and extends the intriguing proposal that IF proteins provide a "molecular sink or sponge" for phosphorylation during key metabolic processes in the cell (Ku and Omary 2006). Other than keratin, neurofilament proteins (Table 1) and, in particular, their tail domains have also been proposed to buffer excess kinase activity in neurons (Nguyen et al. 2001; for a different view, see Lobsiger et al. 2005).

Vimentin and the long-range transport of ERK kinase after CNS injury

Like K17, vimentin was recently implicated in a novel, nonmechanical function at the edge of wounds in the CNS (Perlson et al. 2005). This type III IF gene, whose transcription is highly serum-responsive and broadly manifested during development, becomes highly restricted in the adult, but re-emerges in wound-proximal cells following injury to several tissues (Franke et al.
1982; Lane et al. 1983; Rittling and Baserga 1987; Baldwin and Scheff 1996). After sciatic nerve injury, translation of vimentin and importin- $\beta$ mRNAs is locally activated in the wound-proximal axoplasm, along with phosphorylation-dependent activation of ERK kinases. Newly synthesized vimentin would form a bridge between activated ERK and importin- $\beta$, yielding a "retrograde transport complex" bound for the cell body in a dynein motor- and microtubule-dependent fashion. Here, interaction with vimentin is thought to preserve the activated state of ERKs in the context of "long-range kinase signaling" (Perlson et al. 2005, 2006). Vimentin also fulfills a mechanical support role during wound repair in skin (Eckes et al. 2000) and in the CNS (along with GFAP) (Pekny et al. 1999).

Vimentin is reportedly required for proper ERK regulation in a distinct setting that connects $\beta_{3}$-adrenergic stimulation to the activation of lipolysis in cultured adipocytes (Kumar et al. 2007). In yet another example of its involvement in the response of tissues to injury, vimentin influences the balance between endothelin and nitric oxide signals, and thus affects the response of resistance arteries to flow, following partial nephrectomy in mice (Terzi et al. 1997). That much is now clear: Cytoplasmic IF proteins participate in the regulation of a growing number of signaling pathways operating in a broad array of biological contexts (see below).

\section{Cytoplasmic IFs and cell death via apoptosis: a love-hate relationship}

\section{Cytoplasmic IFs attenuate death receptor-mediated apoptosis}

IF proteins attenuate the response to specific proapoptotic signals in several cell culture models and physiological settings (Caulin et al. 2000; Oshima 2002). This cell-autonomous role can be mediated by various mechanisms, depending on the IF protein involved and biological context. For instance, several type I keratins, including $\mathrm{K} 18, \mathrm{~K} 14$, K16, and K17, bind TRADD, an adaptor protein that is recruited to the liganded TNF receptor 1 and essential for downstream signal relay, including the formation of death-inducing signaling complexes. Inada et al. (2001) provided cell culture-based evidence supporting a sequestration model whereby TRADD's interaction with K18 prevents it from being recruited to activated TNFR1, resulting in signal attenuation. In vivo, abrogation of the keratin-TRADD interaction could account for enhanced susceptibility to TNF $\alpha$ in two contexts: the trophectoderm failure and associated mid-gestational lethality seen in K8-null embryos (Jaquemar et al. 2003) and the premature entry of hair follicles in the involution phase of their growth cycle in K17-null mice (Tong and Coulombe 2006). Of note, K17's ability to modulate $\mathrm{TNF} \alpha$ signaling is genetically independent from its function of structural support (Tong and Coulombe 2006). The K8- and K17-null phenotypes are only partially rescued by $\mathrm{TNF} \alpha$ deficiency (Jaquemar et al. 2003; Tong and Coulombe 2006), indicating that the mechanism(s) through which K8 and K17 promote cell 
survival are complex. In the case of the trophectoderm phenotype, K8/K18 have also been shown to bind the cytoplasmic portion of TNFR2 and LT $\beta$ R receptors (Caulin et al. 2000), and, as mentioned above, their interaction with Mrj is key to their turnover and proper cell homeostasis in that context (Watson et al. 2007).

In mouse liver hepatocytes, lack of $\mathrm{K} 8$ results in a complete absence of keratin filaments and selectively enhances susceptibility to Fas-mediated apoptosis. This trait correlates with an increased density of Fas receptors at the surface (Gilbert et al. 2001) and significant decreases in ERK1/2 activity and in the anti-apoptotic protein c-Flip, which interacts with K8/K18 (Gilbert et al. 2004). The pattern of site-specific phosphorylation on K8/K18 is significantly altered early after Fas receptor stimulation in mouse liver ( $\mathrm{Ku}$ et al. 2003), and modest overexpression of the phosphorylation mutant K8 S73A significantly enhances Fas-mediated apoptosis in transgenic mouse livers (Ku and Omary 2006). It thus appears that the same set of IF proteins can attenuate distinct proapoptotic signals in different tissues.

Last but not least, nestin, an intriguing IF protein expressed in several adult tissue stem cells (Table 1), promotes the survival of neuronal progenitor cells facing oxidative stress and apoptosis, through its ability to scaffold and regulate the activity of the cyclin-dependent kinase 5 (cdk5) and its regulator p35 (Sahlgren et al. 2006). Interactions between select kinases and IFs appear instrumental in regulating signaling toward apoptosis (Ku and Omary 2006; Sahlgren et al. 2006).

\section{Cytoplasmic IFs nucleate the apoptotic machinery and facilitate the execution of death}

As the apoptotic program moves into its execution phase, the self-contained destruction of the cell and its packaging into small, membrane-bound fragments that can be cleanly disposed of by phagocytes requires that the cytoskeleton be rearranged (Moss and Lane 2006). Several IF proteins are directly cleaved, at an early stage, by the effector caspases that drive cell destruction. Cleavage occurs at a conserved location within the rod domain (and at additional sites in some cases) (Fig. 1A), causing loss of filament integrity and destruction of the nuclear and cytoplasmic IF networks (Oshima 2002; Omary et al. 2004). Cleavage is important for the timely execution of apoptosis, as evidenced by the delay incurred when caspase-insensitive forms of lamins (Rao et al. 1996) and desmin (Chen et al. 2003) are overexpressed (see also Schietke et al. 2006). Equally interesting, the caspase 6-mediated cleavage of lamin $\mathrm{A} / \mathrm{C}$ is required for complete chromatin condensation during apoptosis (Ruchaud et al. 2002). The early onset and efficient cleavage of IF proteins may be fostered by physical proximity, as key effectors of the apoptotic machinery, including ubiquitinated DEDD (death effector-containing DNAbinding protein) and procaspase 3, bind cytoplasmic IFs (Lee et al. 2002; Schutte et al. 2006). In the case of DEDD, increased association with keratin IFs correlates with heightened sensitivity to apoptosis in many epithe- lial cell lines (Schutte et al. 2006). Caspase cleavage of IF proteins has further significance. In synovial fibroblasts isolated from rheumatoid arthritis patients, for instance, vimentin cleavage is coupled to the release of filamentbound p53 and its transport to the nucleus, where it can enhance TNF $\alpha$-induced apoptosis (Yang et al. 2005). In the clinic, immune detection of the caspase-generated C-terminal fragment of K18 in serum represents a useful diagnostic tool when assessing the response of cancer patients to therapy (e.g., see Ueno et al. 2003; Bantel et al. 2004).

In a general manner, therefore, cytoplasmic IF proteins tend to antagonize death receptor-induced apoptosis by attenuating the strength of the signals that feed into the formation of death-inducing complexes, but promote apoptosis once commitment to execute it is made. Whether IFs also regulate the mitochondria-dependent, intrinsic apoptotic death pathway is unclear. Many types of IFs reportedly bind mitochondria (for review, see Toivola et al. 2005), and the muscle-specific expression of $\mathrm{Bcl} 2$ rescues the mitochondrial defects and ameliorates the cardiomyopathy that occurs in desmin-null mice (Weisleder et al. 2004).

\section{IFs and vectorial processes: protein targeting, vesicle transport, and cell adhesion}

Vimentin's involvement toward the retrograde transport of ERK1/2 in injured neurons (Perlson et al. 2005), already discussed above, represents one among many findings reflecting the involvement of IF proteins in vectorial, or spatially restricted, processes in the cell. To sum up this new aspect of their function in the cell, IFs have now been shown to participate in the targeting of proteins to specific locations in polarized cells, in the transport and distribution of organelles, and in the regulation of cell-cell and cell-matrix adhesion.

\section{Protein targeting in polarized epithelial cells}

In simple epithelial linings, the formation and maintenance of two domains within the plasma membrane, apical and basolateral, allows for vectorial exchanges between lumen and stroma compartments. Their existence depends in part on the existence of a physical boundary separating them (i.e., tight junctions and other adhesive elements), along with the ability to differentially target specific effector proteins. Recent studies have uncovered protein targeting defects in the gut epithelial lining of mice lacking K8. In the jejunum section of the small intestine, several markers including sucrase-isomaltase, the CFTR chloride ion channel, alkaline phosphatase, and syntaxin-3 (an effector of the SNARE vesicular transport machinery) are either mistargeted or missing from the apical compartment of epithelial cells (Ameen et al. 2001). This is manifested near the tip of villi and not in the crypts, where epithelial cells express a related keratin, K7 (Ameen et al. 2001). In the large intestine, several proteins involved in the regulation of the sodium chlo- 
ride balance including $\mathrm{H}, \mathrm{K}$-ATPase $\beta$ and the sodium transporter $\mathrm{ENaC}$ are aberrantly distributed, while the anion-exchanger- $1 / 2$ is up-regulated. These alterations likely underlie the chronic diarrhea and compensatory hyperplasia seen in K8-null mice surviving to adulthood (Toivola et al. 2004). Down-regulation of K19 in cultured CACO-2 epithelial cells also causes mistargeting of membrane proteins to the apical pole (Salas et al. 1997). In K8-null liver hepatocytes, the normally apical ectoATPase is mislocalized (Satoh et al. 1999; Ameen et al. 2001), and, as discussed above, the Fas receptor is aberrantly displayed at the cell surface (Gilbert et al. 2001).

While the mechanism(s) underlying these surprising defects are unknown, the emerging role of K8/K18/K19 filaments toward the peculiar organization of microtubules in polarized simple epithelial cells (Salas 1999) may play a role. In such cells, the subapical region is enriched in keratin IFs (Fig. 1F), which, in turn, promote a local enrichment of microtubule organizing centers (MTOCs) through the ability of K8 to bind the $\gamma$-tubulin ring complex-binding protein GCP6 (Oriolo et al. 2006). Accordingly, MTOCs are aberrantly localized, leading to microtubule disorganization, in gut epithelial cells lacking K8 (Oriolo et al. 2006). A microtubule-dependent defect has also been invoked to explain the aberrant trafficking of Fas receptors to the surface to K8-null hepatocytes (Gilbert et al. 2001). Also of potential relevance, ezrin transiently associates with keratin IFs at an early stage of the formation of the F-actin-rich apical brush border in intestinal epithelial cells (Wald et al. 2005). Finally, IF proteins have been shown to interact with the microtubule-dependent kinesin and dynein motors (see Helfand et al. 2004; Betz et al. 2006), and with myosins (Jazwinska et al. 2003) including myosin Va (Rao et al. 2002a), an actin-dependent motor specialized in organellar transport. Disruption of any of these interactions could contribute to these IF-dependent protein targeting defects.

\section{IFs and the targeting and regulation of cell} adhesion proteins

It has long been known that cytoplasmic IFs are attached at cell membrane-spanning adhesions complexes specialized toward the maintenance of tissue integrity. These include desmosome cell-cell junctions in epithelia and cardiac muscle, which feature a special class of cadherin cell-cell adhesion molecules, and hemidesmosomes, which are integrin $\alpha_{6} \beta_{4}$-mediated linkages to the extracellular matrix (see Green and Jones 1996; Kottke et al. 2006; Litjens et al. 2006). The molecular underpinnings, physiological importance, and clinical relevance of these linkages are well-defined and have been reviewed elsewhere (Fuchs and Cleveland 1998; Wiche 1998; Getsios et al. 2004; Jefferson et al. 2004; Omary et al. 2004). In recent years, we learned that IFs can also be anchored at cell junctions mediated by classical cadherins (e.g., see Kowalczyk et al. 1998; Kim et al. 2005) and at "nonhemidesmosomal," integrin-mediated linkages to the substratum, such as focal adhesions (e.g., see Tsu- ruta and Jones 2003; Kreis et al. 2005). In this latter case, synemin (Table 1), whose unusually long nonhelical tail domain features binding sites for actin-associated adhesion plaque proteins (Uyama et al. 2006), likely plays a role.

A pair of recent studies highlighted the importance of IFs in regulating integrin-based adhesion in migrating cells. Ivaska et al. (2005) showed that PKCE-dependent phosphorylation of the vimentin head domain controls the exit of integrins from a vesicle- and cytoskeletalbound intracellular compartment to the plasma membrane in migrating mouse embryonic fibroblasts. In addition to providing key insight into the requirement for PKC activity during migration, this finding also reilluminates the classic observation that tumor cell lines showing a high vimentin content show an increased metastatic potential (Hendrix et al. 1996, 1997). In the second study, Nieminen et al. (2006) showed that vimentin-containing IFs form a dynamic anchoring structure at the site of contact made by peripheral blood mononuclear cells (PMBCs) when diapedesis is initiated. Loss of vimentin significantly impairs the homing of PBMCs to mesenteric lymph nodes and spleen, correlating with a drastic loss of the cell-surface exposure, and polarization, of the adhesion molecules ICAM- 1 and VCAM- 1 on PBMCs, and of integrin- $\beta 1$ on endothelial cells. These two studies significantly extend prior work by Brown et al. (2001), who had shown that vimentin is key to the mechanical integrity of lymphocytes while in circulation as well as during diapedesis.

\section{IFs and vesicular transport}

Studies led largely by Faundez and colleagues revealed a role for IF proteins, vimentin in particular, in the traffic of lysosomes (Styers et al. 2004, 2005, 2006). Vimentinnull fibroblasts, which lack IFs altogether (ColucciGuyon et al. 1994), exhibit fewer autophagosomes and an unusual concentration of lysosomes in the perinuclear area (Styers et al. 2004). Conversely, pharmacological or genetic disruption of vesicular transport has a profound impact on vimentin IF organization in fibroblasts (Styers et al. 2006). These defects likely stem from the perturbation of the interaction between vimentin and AP-3, an adaptor complex crucial for the intracellular sorting of a subset of lysosomes as well as several specialized, lysozome-related organelles such as melanosomes and synaptic vesicles (Styers et al. 2004). Reflecting the interdependency of these two "unlikely partners," fibroblasts null for either vimentin or AP-3 share several specific defects, including depressed zinc intracellular stores and a reduced ability to acidify lysosomes (Styers et al. 2004). The mechanism(s) underlying this novel function remains to be defined; possibilities range from simple sequestration, an idea that has already been proposed to account for the significance of vimentin's interaction with SNAP-23 (a protein involved in vesicle fusion) (Faigle et al. 2000), to regulating the association of molecular motors with AP-3-coated vesicles. Vimentin's ability to bind negatively charged phospholipids through 
Table 3. Functions of IFs in the cytoplasm

\begin{tabular}{|c|c|c|}
\hline Description & Shown for the following IF proteins & Comment \\
\hline Structural support & All major types of IF proteins & Universal in the family; defective in many diseases. \\
\hline $\begin{array}{l}\text { Determining cellular } \\
\text { architecture }\end{array}$ & $\begin{array}{l}\text { Keratin, vimentin, desmin, } \\
\text { synemin, neurofilaments }\end{array}$ & $\begin{array}{l}\text { Examples: Proper targeting of adhesion and other } \\
\text { types of membrane proteins in polarized cells; fostering } \\
\text { axonal radial growth; influencing the distribution of MTOCs } \\
\text { and microtubule organization and the positioning/trafficking } \\
\text { of key cellular organelles. }\end{array}$ \\
\hline Regulation of cell growth & Keratin & $\begin{array}{l}\text { Via an impact on the regulation of protein synthesis, } \\
\text { the cell cycle, and the activity of key signaling kinases. }\end{array}$ \\
\hline Regulation of cell death & Keratin, vimentin, nestin & $\begin{array}{l}\text { Attenuation of proapoptotic signals (e.g., TNF } \alpha, \text { Fas); } \\
\text { scaffolding and organization of death effector proteins. }\end{array}$ \\
\hline $\begin{array}{l}\text { Response to injury and to } \\
\text { nonmechanical stresses }\end{array}$ & $\begin{array}{l}\text { Keratin, vimentin, } \\
\text { neurofilament }\end{array}$ & $\begin{array}{l}\text { Involves site-specific phosphorylation; act as scaffolds } \\
\text { for key proteins (kinases); may act as } \\
\text { phosphate "sink" or "sponge." }\end{array}$ \\
\hline
\end{tabular}

its nonhelical head domain could also play a role (e.g., see Horkovics-Kovats and Traub 1990).

This newly defined role is likely fulfilled by other IF proteins in distinct cell types. For instance, AP-3 also binds the neuronal proteins peripherin and $\alpha$-internexin (cf. Table 1; Styers et al. 2004), and there is evidence showing that the directional mobility of vesicles targeted for exocytosis is reduced in astrocytes lacking GFAP and vimentin (Potokar et al. 2007). Studies in humans (Uttam et al. 1996; Betz et al. 2006) and mice (Fitch et al. 2003; McGowan et al. 2006) suggest that keratin IFs impact the intracellular transport and/or distribution of melanin granules in basal layer keratinocytes, thus influencing skin pigmentation in vivo (see Gu and Coulombe 2007). Of note, a deficiency in a subunit of the AP-3 complex accounts for the pigmentation anomalies of the Mocha mouse (Kantheti et al. 1998).

\section{Concluding remarks and future prospects}

Studies having unfolded in the recent past have led to the realization that both nuclear and cytoplasmic IFs perform a broad variety of important functions beyond structural support. We offered here an abbreviated account of what they are (Table 3). A rationale for the large size of this family, and the context-dependent regulation of its individual members, appears to be finally emerging. Multiplicity of sequences, along with promiscuous polymerization rules, engenders a broad range of surface chemistries that may serve IFs well not only toward adapting their roles of mechanical support, but, perhaps more compellingly, also enabling them to promote specialized cytoarchitectures and modulate key signaling pathways in a manner that enhances and supports the differentiated phenotype. However inspiring, such thinking makes a number of assumptions that have yet to be verified by rigorous experimentation (see below). Otherwise, there certainly are additional exciting roles awaiting discovery.

The intriguing question arises as to whether IFs are generally involved in the templating and/or regulation of phosphorylation, and related regulatory signals, in the cell. Other than ERK, cdk5, and cdc25, already covered in this text, various IF proteins bind to many additional kinases, including PKC, PKA, CaMKII, JNK, Akt, Rho kinase, and Raf-1 (for reviews, see Izawa and Inagaki 2006; Omary et al. 2006) and at least two more phosphatases: PP2A (Tao et al. 2006) and PP1c (Oguri et al. 2006). The RACK1-mediated interaction between plectin and PKC $\delta$ is key to the proper regulation of this kinase, and to IF network organization, in skin keratinocytes placed under stress or engaged in migration (Osmanagic-Myers et al. 2006). The idea of IFs as "signaling platforms" (e.g., see Paramio and Jorcano 2002; Coulombe and Wong 2004; Pallari and Eriksson 2006) has officially emerged, and further research is needed to uncover the extent of this phenomenon and how it works.

We are eagerly awaiting the genesis of structural models, with atomic resolution, for various types of polymerized IFs. The progress recently made in defining the core architecture of mature IFs, whether reconstituted in vitro or in their native tissue setting, will help overcome the difficulties experienced while attempting to solve the structure of their subunits (Strelkov et al. 2001). Detailed structural knowledge is needed to understand why IFs are so adept at providing mechanical support, how they actually behave when placed under strain, and, at another level, how the mixing of IF proteins yields polymers with different properties and surface chemistry, the latter being a key determinant for interaction with cellular proteins and associated functions.

One cannot overemphasize the importance of defining how IF assembly and dynamics occur in a live cell and tissue setting, and their regulation. This knowledge is required, as an example, to determine whether IF proteins fulfill their nonmechanical functions as polymers or soluble entities. Conventional wisdom dictates that cellular pools of soluble IF subunits are small $(<5 \%)$ (Soellner et al. 1985; Chou et al. 1993; Bernot et al. 2005). But is this really the case? Nonpolymerized IFs can be "packaged" into large macromolecular complexes within the cell (e.g., see Prahlad et al. 1998; Lu et al. 2005), so that the classical sedimentation-based definition of "polymerized" versus "soluble" pools may be misleading. New assays are needed. At a different level, studies of microtubules and F-actin (Alberts et al. 2002) 
established that a protein conformational switch in polymer-bound subunits is what fuels polymer dynamics at steady state. The same should apply to IFs, prompting the question of the nature of the mechanism involved.

So far, the progress made in defining the roles of cytoplasmic IFs in vivo has originated mostly from studies involving genetically manipulated mice; that is, other species that are more readily tractable genetically have been relatively underexploited. For instance, C. elegans possesses several IF genes, many of them required for surviving late embryogenesis (Karabinos et al. 2001, 2004). The mechanisms underlying this requirement are unknown. Alternatively, the zebrafish genome exhibits a mammalian-like complexity of IF genes (e.g., see Zimek and Weber 2005) and is also well-suited for random mutagenesis coupled with phenotypic screens (Geisler et al. 2007). These species are also readily amenable to live imaging, a powerful approach to define novel IF functions and study the underlying mechanisms (e.g., see Nieminen et al. 2006).

Additional roles for cytoplasmic IFs will emerge from further characterization of already existing mouse models that exhibit intriguing phenotypes. One is the marked hyperproliferation seen in the basal layer of epidermis and sebaceous glands of K10-null mice, in the absence of cell fragility (Reichelt and Magin 2002; Reichelt et al. 2004; see also Santos et al. 2002). Another one is the white-matter stress and other aspects of the CNS phenotype developing in mice engineered to express high levels of GFAP mutants that cause Alexander disease in humans (e.g., see Hagemann et al. 2006). Here again, the pathology extends beyond astrocytes, the primary site of GFAP expression. Another compelling set of mouse findings relates to the phosphorylation-dependent, cell-autonomous, and cytoprotective effect provided by K8/K18 in liver hepatocytes exposed to metabolic toxins (e.g., see Ku et al. 1998). Whether K8/K18 provides a phosphate-acceptor sink that buffers excessive kinase activity, as favored by $\mathrm{Ku}$ and Omary (2006), or the phosphorylated epitopes on these keratins are regulating key effectors of the metabolic stress response, is unclear. Finally, identification of binding partners for IF proteins should continue to be a key source of inspiration for elucidating their roles in the cell, as well as provide a mechanistic basis for interesting phenotypes in genetically manipulated models.

\section{Acknowledgments}

We apologize to those researchers whose original contributions were not directly cited in the text, and extend a special thank you to Drs. Lars Norlen, Kathleen Green, and Diana Toivola for providing great images and to colleagues in the laboratory for their support. This work was made possible by grants AR42047 and AR44232 (to P.A.C.) from the National Institute of Arthritis, Musculoskeletal, and Skin Diseases (NIAMS).

\section{References}

Aebi, U., Fowler, W.E., Rew, P., and Sun, T.T. 1983. The fibrillar substructure of keratin filaments unraveled. J. Cell Biol. 97: 1131-1143.
Aebi, U., Haner, M., Troncoso, J., Eichner, R., and Engel, A. 1988. Unifying principles in intermediate filament assembly. Protoplasma 145: 73-81.

Albers, K. and Fuchs, E. 1987. The expression of mutant epidermal keratin cDNAs transfected in simple epithelial and squamous cell carcinoma lines. J. Cell Biol. 105: 791-806.

Alberts, B., Johnson, A., Lewis, J., Raff, M., Roberts, K., and Walter, P. 2002. Molecular biology of the cell, 4th ed. Garland Science, New York.

Ameen, N.A., Figueroa, Y., and Salas, P.J. 2001. Anomalous apical plasma membrane phenotype in CK8-deficient mice indicates a novel role for intermediate filaments in the polarization of simple epithelia. J. Cell Sci. 114: 563-575.

Andra, K., Lassmann, H., Bittner, R., Shorny, S., Fassler, R., Propst, F., and Wiche, G. 1997. Targeted inactivation of plectin reveals essential function in maintaining the integrity of skin, muscle, and heart cytoarchitecture. Genes \& Dev. 11: 3143-3156.

Ausmees, N., Kuhn, J.R., and Jacobs-Wagner, C. 2003. The bacterial cytoskeleton: An intermediate filament-like function in cell shape. Cell 115: 705-713.

Baldwin, S.A. and Scheff, S.W. 1996. Intermediate filament change in astrocytes following mild cortical contusion. Glia 16: $266-275$.

Ball, E.H. and Singer, S.J. 1981. Association of microtubules and intermediate filaments in normal fibroblasts and its disruption upon transformation by a temperature-sensitive mutant of Rous sarcoma virus. Proc. Natl. Acad. Sci. 78: 6986-6990.

Bantel, H., Lugering, A., Heidemann, J., Volkmann, X., Poremba, C., Strassburg, C.P., Manns, M.P., and SchulzeOsthoff, K. 2004. Detection of apoptotic caspase activation in sera from patients with chronic HCV infection is associated with fibrotic liver injury. Hepatology 40: 1078-1087.

Beil, M., Micoulet, A., von Wichert, G., Paschke, S., Walther, P., Omary, M.B., Van Veldhoven, P.P., Gern, U., Wolff-Hieber, E., Eggermann, J., et al. 2003. Sphingosylphosphorylcholine regulates keratin network architecture and visco-elastic properties of human cancer cells. Nat. Cell Biol. 5: 803-811.

Bellin, R.M., Huiatt, T.W., Critchley, D.R., and Robson, R.M. 2001. Synemin may function to directly link muscle cell intermediate filaments to both myofibrillar Z-lines and costameres. J. Biol. Chem. 276: 32330-32337.

Bernot, K.M., Lee, C.H., and Coulombe, P.A. 2005. A small surface hydrophobic stripe in the coiled-coil domain of type I keratins mediates tetramer stability. J. Cell Biol. 168: 965974.

Bertram, P.G., Zeng, C., Thorson, J., Shaw, A.S., and Zheng, X.F. 1998. The 14-3-3 proteins positively regulate rapamycinsensitive signaling. Curr. Biol. 8: 1259-1267.

Betz, R.C., Planko, L., Eigelshoven, S., Hanneken, S., Pasternack, S.M., Bussow, H., Bogaert, K.V., Wenzel, J., BraunFalco, M., Rutten, A., et al. 2006. Loss-of-function mutations in the keratin 5 gene lead to Dowling-Degos disease. Am. J. Hum. Genet. 78: 510-519.

Bonifas, J.M., Rothman, A.L., and Epstein Jr., E.H. 1991. Epidermolysis bullosa simplex: Evidence in two families for keratin gene abnormalities. Science 254: 1202-1205.

Bonne, G., Di Barletta, M.R., Varnous, S., Becane, H.M., Hammouda, E.H., Merlini, L., Muntoni, F., Greenberg, C.R., Gary, F., Urtizberea, J.A., et al. 1999. Mutations in the gene encoding lamin A/C cause autosomal dominant EmeryDreifuss muscular dystrophy. Nat. Genet. 21: 285-288.

Bousquet, O., Ma, L., Yamada, S., Gu, C., Idei, T., Takahashi, K., Wirtz, D., and Coulombe, P.A. 2001. The nonhelical tail domain of keratin 14 promotes filament bundling and enhances the mechanical properties of keratin intermediate 
filaments in vitro. J. Cell Biol. 155: 747-754.

Broers, J.L., Ramaekers, F.C., Bonne, G., Yaou, R.B., and Hutchison, C.J. 2006. Nuclear lamins: Laminopathies and their role in premature ageing. Physiol. Rev. 86: 967-1008.

Brown, M.J., Hallam, J.A., Colucci-Guyon, E., and Shaw, S. 2001. Rigidity of circulating lymphocytes is primarily conferred by vimentin intermediate filaments. J. Immunol. 166: 6640-6646.

Cai, S.L., Tee, A.R., Short, J.D., Bergeron, J.M., Kim, J., Shen, J., Guo, R., Johnson, C.L., Kiguchi, K., and Walker, C.L. 2006 Activity of TSC2 is inhibited by AKT-mediated phosphorylation and membrane partitioning. J. Cell Biol. 173: 279-289.

Capell, B.C. and Collins, F.S. 2006. Human laminopathies: Nuclei gone genetically awry. Nat. Rev. Genet. 7: 940-952.

Caulin, C., Ware, C.F., Magin, T.M., and Oshima, R.G. 2000. Keratin-dependent, epithelial resistance to tumor necrosis factor-induced apoptosis. J. Cell Biol. 149: 17-22.

Chang, L., Shav-Tal, Y., Trcek, T., Singer, R.H., and Goldman, R.D. 2006. Assembling an intermediate filament network by dynamic cotranslation. J. Cell Biol. 172: 747-758.

Chen, F., Chang, R., Trivedi, M., Capetanaki, Y., and Cryns, V.L. 2003. Caspase proteolysis of desmin produces a dominant-negative inhibitor of intermediate filaments and promotes apoptosis. J. Biol. Chem. 278: 6848-6853.

Chou, C.F., Riopel, C.L., Rott, L.S., and Omary, M.B. 1993. A significant soluble keratin fraction in 'simple' epithelial cells. Lack of an apparent phosphorylation and glycosylation role in keratin solubility. J. Cell Sci. 105: 433-445.

Cleveland, D.W., Monteiro, M.J., Wong, P.C., Gill, S.R., Gearhart, J.D., and Hoffman, P.N. 1991. Involvement of neurofilaments in the radial growth of axons. J. Cell Sci. Suppl. 15: 85-95.

Colucci-Guyon, E., Portier, M.M., Dunia, I., Paulin, D., Pournin, S., and Babinet, C. 1994. Mice lacking vimentin develop and reproduce without an obvious phenotype. Cell 79: 679-694.

Coulombe, P.A. and Omary, M.B. 2002. Hard and soft principles defining the structure, function and regulation of keratin intermediate filaments. Curr. Opin. Cell Biol. 14: 110-122.

Coulombe, P.A. and Wong, P. 2004. Cytoplasmic intermediate filaments revealed as dynamic and multipurpose scaffolds. Nat. Cell Biol. 6: 699-706.

Coulombe, P.A., Chan, Y.M., Albers, K., and Fuchs, E. 1990. Deletions in epidermal keratins leading to alterations in filament organization in vivo and in intermediate filament assembly in vitro. J. Cell Biol. 111: 3049-3064.

Coulombe, P.A., Hutton, M.E., Letai, A., Hebert, A., Paller, A.S., and Fuchs, E. 1991a. Point mutations in human keratin 14 genes of epidermolysis bullosa simplex patients: Genetic and functional analyses. Cell 66: 1301-1311.

Coulombe, P.A., Hutton, M.E., Vassar, R., and Fuchs, E. 1991b. A function for keratins and a common thread among different types of epidermolysis bullosa simplex diseases. I. Cell Biol. 115: 1661-1674.

De Jonghe, P., Mersivanova, I., Nelis, E., Del Favero, J., Martin, J.J., Van Broeckhoven, C., Evgrafov, O., and Timmerman, V. 2001. Further evidence that neurofilament light chain gene mutations can cause Charcot-Marie-Tooth disease type $2 \mathrm{E}$. Ann. Neurol. 49: 245-249.

DePianto, D. and Coulombe, P.A. 2004. Intermediate filaments and tissue repair. Exp. Cell Res. 301: 68-86.

De Sandre-Giovannoli, A., Chaouch, M., Kozlov, S., Vallat, J.M., Tazir, M., Kassouri, N., Szepetowski, P., Hammadouche, T., Vandenberghe, A., Stewart, C.L., et al. 2002. Homozygous defects in LMNA, encoding lamin A/C nuclear-envelope proteins, cause autosomal recessive axonal neuropathy in human (Charcot-Marie-Tooth disorder type 2) and mouse. Am. J. Hum. Genet. 70: 726-736.

Eckes, B., Colucci-Guyon, E., Smola, H., Nodder, S., Babinet, C., Krieg, T., and Martin, P. 2000. Impaired wound healing in embryonic and adult mice lacking vimentin. J. Cell Sci. 113: 2455-2462.

Erber, A., Riemer, D., Bovenschulte, M., and Weber, K. 1998. Molecular phylogeny of metazoan intermediate filament proteins. J. Mol. Evol. 47: 751-762.

Er Rafik, M., Doucet, J., and Briki, F. 2004. The intermediate filament architecture as determined by X-ray diffraction modeling of hard $\alpha$-keratin. Biophys. J. 86: 3893-3904.

Evgrafov, O.V., Mersiyanova, I., Irobi, J., Van Den Bosch, L., Dierick, I., Leung, C.L., Schagina, O., Verpoorten, N., Van Impe, K., Fedotov, V., et al. 2004. Mutant small heat-shock protein 27 causes axonal Charcot-Marie-Tooth disease and distal hereditary motor neuropathy. Nat. Genet. 36: 602606.

Faigle, W., Colucci-Guyon, E., Louvard, D., Amigorena, S., and Galli, T. 2000. Vimentin filaments in fibroblasts are a reservoir for SNAP23, a component of the membrane fusion machinery. Mol. Biol. Cell 11: 3485-3494.

Fitch, K.R., McGowan, K.A., van Raamsdonk, C.D., Fuchs, H., Lee, D., Puech, A., Herault, Y., Threadgill, D.W., Hrabe de Angelis, M., and Barsh, G.S. 2003. Genetics of dark skin in mice. Genes \& Dev. 17: 214-228.

Franke, W.W., Grund, C., Kuhn, C., Jackson, B.W., and Illmensee, K. 1982. Formation of cytoskeletal elements during mouse embryogenesis. III. Primary mesenchymal cells and the first appearance of vimentin filaments. Differentiation 23: 43-59.

Fuchs, E. and Cleveland, D.W. 1998. A structural scaffolding of intermediate filaments in health and disease. Science 279: 514-519.

Fuchs, E. and Coulombe, P.A. 1992. Of mice and men: Genetic skin diseases of keratin. Cell 69: 899-902.

Fuchs, E. and Weber, K. 1994. Intermediate filaments: Structure, dynamics, function, and disease. Annu. Rev. Biochem. 63: $345-382$.

Galarneau, L., Loranger, A., Gilbert, S., and Marceau, N. 2007. Keratins modulate hepatic cell adhesion, size and G1/S transition. Exp. Cell Res. 313: 179-194.

Garcia, M.L., Lobsiger, C.S., Shah, S.B., Deerinck, T.J., Crum, J., Young, D., Ward, C.M., Crawford, T.O., Gotow, T., Uchiyama, Y., et al. 2003. NF-M is an essential target for the myelin-directed 'outside-in' signaling cascade that mediates radial axonal growth. J. Cell Biol. 163: 1011-1020.

Geisler, R., Rauch, G.J., Geiger-Rudolph, S., Albrecht, A., van Bebber, F., Berger, A., Busch-Nentwich, E., Dahm, R., Dekens, M.P., Dooley, C., et al. 2007. Large-scale mapping of mutations affecting zebrafish development. BMC Genomics 8: 11.

Getsios, S., Huen, A.C., and Green, K.J. 2004. Working out the strength and flexibility of desmosomes. Nat. Rev. Mol. Cell Biol. 5: 271-281.

Gilbert, S., Loranger, A., Daigle, N., and Marceau, N. 2001. Simple epithelium keratins 8 and 18 provide resistance to Fas-mediated apoptosis. The protection occurs through a receptor-targeting modulation. J. Cell Biol. 154: 763-774.

Gilbert, S., Loranger, A., and Marceau, N. 2004. Keratins modulate c-Flip/extracellular signal-regulated kinase 1 and 2 antiapoptotic signaling in simple epithelial cells. Mol. Cell. Biol. 24: 7072-7081.

Goldfarb, L.G., Park, K.Y., Cervenakova, L., Gorokhova, S., Lee, H.S., Vasconcelos, O., Nagle, J.W., Semino-Mora, C., Sivakumar, K., and Dalakas, M.C. 1998. Missense mutations in 
desmin associated with familial cardiac and skeletal myopathy. Nat. Genet. 19: 402-403.

Green, K.J. and Jones, J.C. 1996. Desmosomes and hemidesmosomes: Structure and function of molecular components. FASEB J. 10: 871-881.

Green, K.J., Bohringer, M., Gocken, T., and Jones, J.C. 2005. Intermediate filament associated proteins. Adv. Protein Chem. 70: 143-202.

Gruenbaum, Y., Margalit, A., Goldman, R.D., Shumaker, D.K., and Wilson, K.L. 2005. The nuclear lamina comes of age. Nat. Rev. Mol. Cell Biol. 6: 21-31.

$\mathrm{Gu}$, L.H. and Coulombe, P.A. 2005. Defining the properties of the nonhelical tail domain in type II keratin 5: Insight from a bullous disease-causing mutation. Mol. Biol. Cell 16: $1427-$ 1438.

$\mathrm{Gu}, \mathrm{L} . \mathrm{H}$. and Coulombe, P.A. 2007. Keratin function in skin epithelia: A broadening palette with surprising shades. Curr. Opin. Cell Biol. 19: 13-23.

Guzman, C., Jeney, S., Kreplak, L., Kasas, S., Kulik, A.J., Aebi, U., and Forro, L. 2006. Exploring the mechanical properties of single vimentin intermediate filaments by atomic force microscopy. J. Mol. Biol. 360: 623-630.

Haddad, L.A., Smith, N., Bowser, M., Niida, Y., Murthy, V., Gonzalez-Agosti, C., and Ramesh, V. 2002. The TSC1 tumor suppressor hamartin interacts with neurofilament-L and possibly functions as a novel integrator of the neuronal cytoskeleton. J. Biol. Chem. 277: 44180-44186.

Hagemann, T.L., Connor, J.X., and Messing, A. 2006. Alexander disease-associated glial fibrillary acidic protein mutations in mice induce Rosenthal fiber formation and a white matter stress response. J. Neurosci. 26: 11162-11173.

Hanukoglu, I. and Fuchs, E. 1982. The cDNA sequence of a human epidermal keratin: Divergence of sequence but conservation of structure among intermediate filament proteins. Cell 31: 243-252.

Hatzfeld, M. and Weber, K. 1991. Modulation of keratin intermediate filament assembly by single amino acid exchanges in the consensus sequence at the C-terminal end of the rod domain. J. Cell Sci. 99: 351-362.

Helfand, B.T., Chang, L., and Goldman, R.D. 2004. Intermediate filaments are dynamic and motile elements of cellular architecture. J. Cell Sci. 117: 133-141.

Helmke, B.P., Goldman, R.D., and Davies, P.F. 2000. Rapid displacement of vimentin intermediate filaments in living endothelial cells exposed to flow. Circ. Res. 86: 745-752.

Hendrix, M.J., Seftor, E.A., Chu, Y.W., Trevor, K.T., and Seftor, R.E. 1996. Role of intermediate filaments in migration, invasion and metastasis. Cancer Metastasis Rev. 15: 507-525.

Hendrix, M.J., Seftor, E.A., Seftor, R.E., and Trevor, K.T. 1997. Experimental co-expression of vimentin and keratin intermediate filaments in human breast cancer cells results in phenotypic interconversion and increased invasive behavior. Am. I. Pathol. 150: 483-495.

Henrion, D., Terzi, F., Matrougui, K., Duriez, M., Boulanger, C.M., Colucci-Guyon, E., Babinet, C., Briand, P., Friedlander, G., Poitevin, P., et al. 1997. Impaired flow-induced dilation in mesenteric resistance arteries from mice lacking vimentin. J. Clin. Invest. 100: 2909-2914.

Herrmann, H. and Aebi, U. 2004. Intermediate filaments: Molecular structure, assembly mechanism, and integration into functionally distinct intracellular scaffolds. Annu. Rev. Biochem. 73: 749-789.

Hess, J.F., Budamagunta, M.S., Voss, J.C., and FitzGerald, P.G. 2004. Structural characterization of human vimentin rod 1 and the sequencing of assembly steps in intermediate filament formation in vitro using site-directed spin labeling and electron paramagnetic resonance. J. Biol. Chem. 279: 4484144846.

Hesse, M., Magin, T.M., and Weber, K. 2001. Genes for intermediate filament proteins and the draft sequence of the human genome: Novel keratin genes and a surprisingly high number of pseudogenes related to keratin genes 8 and 18. J. Cell Sci. 114: 2569-2575.

Hirokawa, N., Glicksman, M.A., and Willard, M.B. 1984. Organization of mammalian neurofilament polypeptides within the neuronal cytoskeleton. J. Cell Biol. 98: 1523-1536.

Horkovics-Kovats, S. and Traub, P. 1990. Specific interaction of the intermediate filament protein vimentin and its isolated $\mathrm{N}$-terminus with negatively charged phospholipids as determined by vesicle aggregation, fusion, and leakage measurements. Biochemistry 29: 8652-8657.

Inada, H., Izawa, I., Nishizawa, M., Fujita, E., Kiyono, T., Takahashi, T., Momoi, T., and Inagaki, M. 2001. Keratin attenuates tumor necrosis factor-induced cytotoxicity through association with TRADD. J. Cell Biol. 155: 415-426.

Irvine, A.D. and McLean, W.H. 1999. Human keratin diseases: The increasing spectrum of disease and subtlety of the phenotype-genotype correlation. Br. J. Dermatol. 140: 815-828.

Isaacs, W.B., Cook, R.K., Van Atta, J.C., Redmond, C.M., and Fulton, A.B. 1989. Assembly of vimentin in cultured cells varies with cell type. J. Biol. Chem. 264: 17953-17960.

Ishikawa, H., Bischoff, R., and Holtzer, H. 1968. Mitosis and intermediate-sized filaments in developing skeletal muscle. J. Cell Biol. 38: 538-555.

Ivaska, J., Vuoriluoto, K., Huovinen, T., Izawa, I., Inagaki, M., and Parker, P.J. 2005. PKC $\varepsilon$-mediated phosphorylation of vimentin controls integrin recycling and motility. EMBO J. 24: 3834-3845.

Izawa, I. and Inagaki, M. 2006. Regulatory mechanisms and functions of intermediate filaments: A study using site- and phosphorylation state-specific antibodies. Cancer Sci. 97: 167-174.

Izawa, I., Nishizawa, M., Ohtakara, K., Ohtsuka, K., Inada, H., and Inagaki, M. 2000. Identification of Mrj, a DnaJ/Hsp40 family protein, as a keratin $8 / 18$ filament regulatory protein. J. Biol. Chem. 275: 34521-34527.

Jaquemar, D., Kupriyanov, S., Wankell, M., Avis, J., Benirschke, K., Baribault, H., and Oshima, R.G. 2003. Keratin 8 protection of placental barrier function. J. Cell Biol. 161: 749-756.

Jazwinska, A., Ehler, E., and Hughes, S.M. 2003. Intermediate filament-co-localized molecules with myosin heavy chain epitopes define distinct cellular domains in hair follicles and epidermis. BMC Cell Biol. 4: 10.

Jefferson, J.J., Leung, C.L., and Liem, R.K. 2004. Plakins: Goliaths that link cell junctions and the cytoskeleton. Nat. Rev. Mol. Cell Biol. 5: 542-553.

Kantheti, P., Qiao, X., Diaz, M.E., Peden, A.A., Meyer, G.E., Carskadon, S.L., Kapfhamer, D., Sufalko, D., Robinson, M.S., Noebels, J.L., et al. 1998. Mutation in AP-3 $\delta$ in the mocha mouse links endosomal transport to storage deficiency in platelets, melanosomes, and synaptic vesicles. Neuron 21: 111-122.

Karabinos, A., Schmidt, H., Harborth, J., Schnabel, R., and Weber, K. 2001. Essential roles for four cytoplasmic intermediate filament proteins in Caenorhabditis elegans development. Proc. Natl. Acad. Sci. 98: 7863-7868.

Karabinos, A., Schunemann, J., and Weber, K. 2004. Most genes encoding cytoplasmic intermediate filament (IF) proteins of the nematode Caenorhabditis elegans are required in late embryogenesis. Eur. J. Cell Biol. 83: 457-468.

Kim, Y.J., Sauer, C., Testa, K., Wahl, J.K., Svoboda, R.A., Johnson, K.R., Wheelock, M.J., and Knudsen, K.A. 2005. 
Modulating the strength of cadherin adhesion: Evidence for a novel adhesion complex. J. Cell Sci. 118: 3883-3894.

Kim, S., Wong, P., and Coulombe, P.A. 2006. A keratin cytoskeletal protein regulates protein synthesis and epithelial cell growth. Nature 441: 362-365.

Kiss, B., Karsai, A., and Kellermayer, M.S. 2006. Nanomechanical properties of desmin intermediate filaments. I. Struct. Biol. 155: 327-339.

Kottke, M.D., Delva, E., and Kowalczyk, A.P. 2006. The desmosome: Cell science lessons from human diseases. J. Cell Sci. 119: $797-806$.

Kowalczyk, A.P., Navarro, P., Dejana, E., Bornslaeger, E.A., Green, K.J., Kopp, D.S., and Borgwardt, J.E. 1998. VE-cadherin and desmoplakin are assembled into dermal microvascular endothelial intercellular junctions: A pivotal role for plakoglobin in the recruitment of desmoplakin to intercellular junctions. J. Cell Sci. 111: 3045-3057.

Kreis, S., Schonfeld, H.J., Melchior, C., Steiner, B., and Kieffer, N. 2005. The intermediate filament protein vimentin binds specifically to a recombinant integrin $\alpha 2 / \beta 1$ cytoplasmic tail complex and co-localizes with native $\alpha 2 / \beta 1$ in endothelial cell focal adhesions. Exp. Cell Res. 305: 110-121.

Ku, N.O. and Omary, M.B. 2000. Keratins turn over by ubiquitination in a phosphorylation-modulated fashion. J. Cell Biol. 149: 547-552.

Ku, N.O. and Omary, M.B. 2006. A disease- and phosphorylation-related nonmechanical function for keratin 8. J. Cell Biol. 174: 115-125.

Ku, N.O., Michie, S.A., Soetikno, R.M., Resurreccion, E.Z., Broome, R.L., and Omary, M.B. 1998. Mutation of a major keratin phosphorylation site predisposes to hepatotoxic injury in transgenic mice. J. Cell Biol. 143: 2023-2032.

$\mathrm{Ku}$, N.O., Michie, S., Resurreccion, E.Z., Broome, R.L., and Omary, M.B. 2002. Keratin binding to 14-3-3 proteins modulates keratin filaments and hepatocyte mitotic progression. Proc. Natl. Acad. Sci. 99: 4373-4378.

Ku, N.O., Soetikno, R.M., and Omary, M.B. 2003. Keratin mutation in transgenic mice predisposes to Fas but not TNFinduced apoptosis and massive liver injury. Hepatology 37: 1006-1014.

Kumar, N., Robidoux, J., Daniel, K.W., Guzman, G., Floering, L.M., and Collins, S. 2007. Requirement of vimentin filament assembly for $\beta 3$-adrenergic receptor activation of ERK MAP kinase and lipolysis. J. Biol. Chem. 282: 9244-9250.

Lammerding, J., Schulze, P.C., Takahashi, T., Kozlov, S., Sullivan, T., Kamm, R.D., Stewart, C.L., and Lee, R.T. 2004. Lamin A/C deficiency causes defective nuclear mechanics and mechanotransduction. J. Clin. Invest. 113: 370-378.

Lane, E.B., Hogan, L.M., Kurikinen, M., and Garrels, J.I. 1983. Co-expression of vimentin and cytokeratin in parietal endoderm cells of early mouse embryo. Nature 303: 701-704.

Lane, E.B., Rugg, E.L., Navsaria, H., Leigh, I.M., Heagerty, A.H., Ishida, Y.A., and Eady, R.A. 1992. A mutation in the conserved helix termination peptide of keratin 5 in hereditary skin blistering. Nature 356: 244-246.

Lariviere, R.C. and Julien, J.P. 2004. Functions of intermediate filaments in neuronal development and disease. I. Neurobiol. 58: 131-148.

Lazarides, E. 1980. Desmin and intermediate filaments in muscle cells. Results Probl. Cell Differ. 11: 124-131.

Lee, J.C., Schickling, O., Stegh, A.H., Oshima, R.G., Dinsdale, D., Cohen, G.M., and Peter, M.E. 2002. DEDD regulates degradation of intermediate filaments during apoptosis. J. Cell Biol. 158: 1051-1066.

Letai, A., Coulombe, P.A., McCormick, M.B., Yu, Q.C., Hutton, E., and Fuchs, E. 1993. Disease severity correlates with po- sition of keratin point mutations in patients with epidermolysis bullosa simplex. Proc. Natl. Acad. Sci. 90: 31973201.

Li, H., Guo, Y., Teng, J., Ding, M., Yu, A.C., and Chen, J. 2006. 14-3-3 $\gamma$ affects dynamics and integrity of glial filaments by binding to phosphorylated GFAP. J. Cell Sci. 119: 44524461.

Liao, J. and Omary, M.B. 1996. 14-3-3 proteins associate with phosphorylated simple epithelial keratins during cell cycle progression and act as a solubility cofactor. J. Cell Biol. 133: 345-357.

Lin, L., Holbro, T., Alonso, G., Gerosa, D., and Burger, M.M. 2001. Molecular interaction between human tumor marker protein p150, the largest subunit of eIF3, and intermediate filament protein K7. J. Cell. Biochem. 80: 483-490.

Litjens, S.H., de Pereda, J.M., and Sonnenberg, A. 2006. Current insights into the formation and breakdown of hemidesmosomes. Trends Cell Biol. 16: 376-383.

Lloyd, C., Yu, Q.C., Cheng, J., Turksen, K., Degenstein, L., Hutton, E., and Fuchs, E. 1995. The basal keratin network of stratified squamous epithelia: Defining K15 function in the absence of K14. J. Cell Biol. 129: 1329-1344.

Lobsiger, C.S., Garcia, M.L., Ward, C.M., and Cleveland, D.W. 2005. Altered axonal architecture by removal of the heavily phosphorylated neurofilament tail domains strongly slows superoxide dismutase 1 mutant-mediated ALS. Proc. Natl. Acad. Sci. 102: 10351-10356.

Lu, H., Hesse, M., Peters, B., and Magin, T.M. 2005. Type II keratins precede type I keratins during early embryonic development. Eur. J. Cell Biol. 84: 709-718.

Ma, L., Yamada, S., Wirtz, D., and Coulombe, P.A. 2001. A 'hot-spot' mutation alters the mechanical properties of keratin filament networks. Nat. Cell Biol. 3: 503-506.

Margolis, S.S., Perry, J.A., Forester, C.M., Nutt, L.K., Guo, Y., Jardim, M.J., Thomenius, M.J., Freel, C.D., Darbandi, R., Ahn, J.H., et al. 2006. Role for the PP2A/B568 phosphatase in regulating 14-3-3 release from Cdc25 to control mitosis. Cell 127: 759-773.

Mattout, A., Dechat, T., Adam, S.A., Goldman, R.D., and Gruenbaum, Y. 2006. Nuclear lamins, diseases and aging. Curr. Opin. Cell Biol. 18: 335-341.

Mazzalupo, S., Wong, P., Martin, P., and Coulombe, P.A. 2003. Role for keratins 6 and 17 during wound closure in embryonic mouse skin. Dev. Dyn. 226: 356-365.

McGowan, K.A., Aradhya, S., Fuchs, H., de Angelis, M.H., and Barsh, G.S. 2006. A mouse keratin 1 mutation causes dark skin and epidermolytic hyperkeratosis. J. Invest. Dermatol. 126: 1013-1016.

McLean, W.H., Pulkkinen, L., Smith, F.J., Rugg, E.L., Lane, E.B., Bullrich, F., Burgeson, R.E., Amano, S., Hudson, D.L., Owaribe, K., et al. 1996. Loss of plectin causes epidermolysis bullosa with muscular dystrophy: cDNA cloning and genomic organization. Genes \& Dev. 10: 1724-1735.

Mersiyanova, I.V., Perepelov, A.V., Polyakov, A.V., Sitnikov, V.F., Dadali, E.L., Oparin, R.B., Petrin, A.N., and Evgrafov, O.V. 2000. A new variant of Charcot-Marie-Tooth disease type 2 is probably the result of a mutation in the neurofilament-light gene. Am. J. Hum. Genet. 67: 37-46.

Moss, D.K. and Lane, J.D. 2006. Microtubules: Forgotten players in the apoptotic execution phase. Trends Cell Biol. 16: 330338.

Muñoz-Mármol, A.M., Strasser, G., Isamat, M., Coulombe, P.A., Yang, Y.M., Roca, X., Vela, E., Mate, J.L., Coll, J., Fernández-Figueras, M.T., et al. 1998. A dysfunctional desmin mutation in a patient with severe generalized myopathy. Proc. Natl. Acad. Sci. 95: 11312-11317. 
Navarro, C.L., Cau, P., and Levy, N. 2006. Molecular bases of progeroid syndromes. Hum. Mol. Genet. 15: R151-R161.

Nguyen, M.D., Lariviere, R.C., and Julien, J.P. 2001. Deregulation of Cdk5 in a mouse model of ALS: Toxicity alleviated by perikaryal neurofilament inclusions. Neuron 30: 135-147.

Nieminen, M., Henttinen, T., Merinen, M., Marttila-Ichihara, F., Eriksson, J.E., and Jalkanen, S. 2006. Vimentin function in lymphocyte adhesion and transcellular migration. Nat. Cell Biol. 8: 156-162.

Norlen, L. and Al-Amoudi, A. 2004. Stratum corneum keratin structure, function, and formation: The cubic rod-packing and membrane templating model. J. Invest. Dermatol. 123: 715-732.

Oguri, T., Inoko, A., Shima, H., Izawa, I., Arimura, N., Yamaguchi, T., Inagaki, N., Kaibuchi, K., Kikuchi, K., and Inagaki, M. 2006. Vimentin-Ser82 as a memory phosphorylation site in astrocytes. Genes Cells 11: 531-540.

Omary, M.B., Coulombe, P.A., and McLean, W.H.I. 2004. Intermediate filament proteins and their associated diseases. $N$. Eng1. J. Med. 351: 2087-2100.

Omary, M.B., Ku, N.O., Tao, G.Z., Toivola, D.M., and Liao, J. 2006. 'Heads and tails' of intermediate filament phosphorylation: Multiple sites and functional insights. Trends Biochem. Sci. 31: 383-394.

Oriolo, A.S., Wald, F.A., Canessa, G., and Salas, P.J. 2006. GCP6 binds to intermediate filaments: A novel function of keratins in the organization of microtubules in epithelial cells. Mol. Biol. Cell 18: 781-794.

Oshima, R.G. 2002. Apoptosis and keratin intermediate filaments. Cell Death Differ. 9: 486-492.

Osmanagic-Myers, S., Gregor, M., Walko, G., Burgstaller, G., Reipert, S., and Wiche, G. 2006. Plectin-controlled keratin cytoarchitecture affects MAP kinases involved in cellular stress response and migration. J. Cell Biol. 174: 557-568.

Pallari, H.M. and Eriksson, J.E. 2006. Intermediate filaments as signaling platforms. Sci. STKE 366: 53.

Paramio, J.M. and Jorcano, J.L. 2002. Beyond structure: Do intermediate filaments modulate signalling? Bioessays 24: 836-844.

Parry, D.A. 2005. Microdissection of the sequence and structure of intermediate filament chains. Adv. Protein Chem. 70: $113-142$.

Pekny, M., Johansson, C.B., Eliasson, C., Stakeberg, J., Wallèn, A., Perlmann, T., Lendahl, U., Betsholtz, C., Berthold, C.H., and Frisèn, J. 1999. Abnormal reaction to central nervous system injury in mice lacking glial fibrillary acidic protein and vimentin. J. Cell Biol. 145: 503-514.

Perlson, E., Hanz, S., Ben-Yaakov, K., Segal-Ruder, Y., Seger, R., and Fainzilber, M. 2005. Vimentin-dependent spatial translocation of an activated MAP kinase in injured nerve. Neuron 45: 715-726.

Perlson, E., Michaelevski, I., Kowalsman, N., Ben-Yaakov, K., Shaked, M., Seger, R., Eisenstein, M., and Fainzilber, M. 2006. Vimentin binding to phosphorylated Erk sterically hinders enzymatic dephosphorylation of the kinase. J. Mol. Biol. 364: 938-944.

Perng, M.D., Cairns, L., van den IJssel, P., Prescott, A., Hutcheson, A.M., and Quinlan, R.A. 1999. Intermediate filament interactions can be altered by HSP27 and $\alpha$ B-crystallin. $J$. Cell Sci. 112: 2099-2112.

Peters, B., Kirfel, J., Bussow, H., Vidal, M., and Magin, T.M. 2001. Complete cytolysis and neonatal lethality in keratin 5 knockout mice reveal its fundamental role in skin integrity and in epidermolysis bullosa simplex. Mol. Biol. Cell 12: 1775-1789.

Porter, R.M. and Lane, E.B. 2003. Phenotypes, genotypes and their contribution to understanding keratin function. Trends Genet. 19: 278-285.

Potokar, M., Kreft, M., Li, L., Daniel Andersson, J., Pangrsic, T., Chowdhury, H.H., Pekny, M., and Zorec, R. 2007. Cytoskeleton and vesicle mobility in astrocytes. Traffic 8: 12-20.

Prahlad, V., Yoon, M., Moir, R.D., Vale, R.D., and Goldman, R.D. 1998. Rapid movements of vimentin on microtubule tracks: Kinesin-dependent assembly of intermediate filament networks. J. Cell Biol. 143: 159-170.

Rao, L., Perez, D., and White, E. 1996. Lamin proteolysis facilitates nuclear events during apoptosis. J. Cell Biol. 135: 14411455.

Rao, M.V., Engle, L.J., Mohan, P.S., Yuan, A., Qiu, D., Cataldo, A., Hassinger, L., Jacobsen, S., Lee, V.M., Andreadis, A., et al. 2002a. Myosin Va binding to neurofilaments is essential for correct myosin Va distribution and transport and neurofilament density. J. Cell Biol. 159: 279-290.

Rao, M.V., Garcia, M.L., Miyazaki, Y., Gotow, T., Yuan, A., Mattina, S., Ward, C.M., Calcutt, N.A., Uchiyama, Y., Nixon, R.A., et al. 2002b. Gene replacement in mice reveals that the heavily phosphorylated tail of neurofilament heavy subunit does not affect axonal caliber or the transit of cargoes in slow axonal transport. J. Cell Biol. 158: 681-693.

Reichelt, J. and Magin, T.M. 2002. Hyperproliferation, induc-

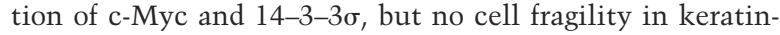
10-null mice. J. Cell Sci. 115: 2639-2650.

Reichelt, J., Furstenberger, G., and Magin, T.M. 2004. Loss of keratin 10 leads to mitogen-activated protein kinase (MAPK) activation, increased keratinocyte turnover, and decreased tumor formation in mice. J. Invest. Dermatol. 123: 973-981.

Ridge, K.M., Linz, L., Flitney, F.W., Kuczmarski, E., Chou, Y.H., Omary, M.B., Sznajder, J.I., and Goldman, R.D. 2005. Keratin 8 phosphorylation by PKC $\delta$ regulates shear stress-mediated disassembly of keratin intermediate filaments in alveolar epithelial cells. J. Biol. Chem. 280: 30400-30405.

Rittling, S.R. and Baserga, R. 1987. Functional analysis and growth factor regulation of the human vimentin promoter. Mol. Cell. Biol. 7: 3908-3915.

Ruchaud, S., Korfali, N., Villa, P., Kottke, T.J., Dingwall, C., Kaufmann, S.H., and Earnshaw, W.C. 2002. Caspase-6 gene disruption reveals a requirement for lamin A cleavage in apoptotic chromatin condensation. EMBO J. 21: 1967-1977.

Sahlgren, C.M., Pallari, H.M., He, T., Chou, Y.H., Goldman, R.D., and Eriksson, J.E. 2006. A nestin scaffold links Cdk5/ p35 signaling to oxidant-induced cell death. EMBO J. 25: 4808-4819.

Salas, P.J. 1999. Insoluble $\gamma$-tubulin-containing structures are anchored to the apical network of intermediate filaments in polarized CACO-2 epithelial cells. J. Cell Biol. 146: 645-658.

Salas, P.J., Rodriguez, M.L., Viciana, A.L., Vega-Salas, D.E., and Hauri, H.P. 1997. The apical submembrane cytoskeleton participates in the organization of the apical pole in epithelial cells. J. Cell Biol. 137: 359-375.

Santos, M., Paramio, J.M., Bravo, A., Ramirez, A., and Jorcano, J.L. 2002. The expression of keratin K10 in the basal layer of the epidermis inhibits cell proliferation and prevents skin tumorigenesis. J. Biol. Chem. 277: 19122-19130.

Satoh, M.I., Hovington, H., and Cadrin, M. 1999. Reduction of cytochemical ecto-ATPase activities in keratin 8-deficient FVB/N mouse livers. Med. Electron Microsc. 32: 209-212.

Satoh, J., Yamamura, T., and Arima, K. 2004. The 14-3-3 protein $\varepsilon$ isoform expressed in reactive astrocytes in demyelinating lesions of multiple sclerosis binds to vimentin and glial fibrillary acidic protein in cultured human astrocytes. Am. J. Pathol. 165: 577-592.

Schietke, R., Brohl, D., Wedig, T., Mucke, N., Herrmann, H., 
and Magin, T.M. 2006. Mutations in vimentin disrupt the cytoskeleton in fibroblasts and delay execution of apoptosis. Eur. J. Cell Biol. 85: 1-10.

Schutte, B., Henfling, M., and Ramaekers, F.C. 2006. DEDD association with cytokeratin filaments correlates with sensitivity to apoptosis. Apoptosis 11: 1561-1572.

Schweizer, J., Bowden, P.E., Coulombe, P.A., Langbein, L., Lane, E.B., Magin, T.M., Maltais, L., Omary, M.B., Parry, D.A., Rogers, M.A., et al. 2006. New consensus nomenclature for mammalian keratins. J. Cell Biol. 174: 169-174.

Smith, F.J., Eady, R.A., Leigh, I.M., McMillan, J.R., Rugg, E.L., Kelsell, D.P., Bryant, S.P., Spurr, N.K., Geddes, J.F., Kirtschig, G., et al. 1996. Plectin deficiency results in muscular dystrophy with epidermolysis bullosa. Nat. Genet. 13: 450-457.

Soellner, P., Quinlan, R.A., and Franke, W.W. 1985. Identification of a distinct soluble subunit of an intermediate filament protein: Tetrameric vimentin from living cells. Proc. Natl. Acad. Sci. 82: 7929-7933.

Sokolova, A.V., Kreplak, L., Wedig, T., Mucke, N., Svergun, D.I., Herrmann, H., Aebi, U., and Strelkov, S.V. 2006. Monitoring intermediate filament assembly by small-angle X-ray scattering reveals the molecular architecture of assembly intermediates. Proc. Natl. Acad. Sci. 103: 16206-16211.

Stewart, M. and Roberts, T.M. 2005. Cytoskeleton dynamics powers nematode sperm motility. Adv. Protein Chem. 71: 383-399.

Strelkov, S.V., Herrmann, H., Geisler, N., Lustig, A., Ivaninskii, S., Zimbelmann, R., Burkhard, P., and Aebi, U. 2001. Divideand-conquer crystallographic approach towards an atomic structure of intermediate filaments. J. Mol. Biol. 306: 773781.

Styers, M.L., Salazar, G., Love, R., Peden, A.A., Kowalczyk, A.P., and Faundez, V. 2004. The endo-lysosomal sorting machinery interacts with the intermediate filament cytoskeleton. Mol. Biol. Cell 15: 5369-5382.

Styers, M.L., Kowalczyk, A.P., and Faundez, V. 2005. Intermediate filaments and vesicular membrane traffic: The odd couple's first dance? Traffic 6: 359-365.

Styers, M.L., Kowalczyk, A.P., and Faundez, V. 2006. Architecture of the vimentin cytoskeleton is modified by perturbation of the GTPase ARF1. J. Cell Sci. 119: 3643-3654.

Suresh, S., Spatz, J., Mills, J.P., Micoulet, A., Dao, M., Lim, C.T., Beil, M., and Seufferlein, T. 2005. Connections between single-cell biomechanics and human disease states: Gastrointestinal cancer and malaria. Acta Biomater. 1: 15-30.

Svitkina, T.M., Verkhovsky, A.B., and Borisy, G.G. 1996. Plectin sidearms mediate interaction of intermediate filaments with microtubules and other components of the cytoskeleton. J. Cell Biol. 135: 991-1007.

Tao, G.Z., Toivola, D.M., Zhou, Q., Strnad, P., Xu, B., Michie, S.A., and Omary, M.B. 2006. Protein phosphatase-2A associates with and dephosphorylates keratin 8 after hyposmotic stress in a site- and cell-specific manner. J. Cell Sci. 119: $1425-1432$

Terzi, F., Henrion, D., Colucci-Guyon, E., Federici, P., Babinet, C., Levy, B.I., Briand, P., and Friedlander, G. 1997. Reduction of renal mass is lethal in mice lacking vimentin. Role of endothelin-nitric oxide imbalance. J. Clin. Invest. 100: $1520-1528$.

Toivola, D.M., Krishnan, S., Binder, H.J., Singh, S.K., and Omary, M.B. 2004. Keratins modulate colonocyte electrolyte transport via protein mistargeting. J. Cell Biol. 164: $911-$ 921.

Toivola, D.M., Tao, G.Z., Habtezion, A., Liao, J., and Omary, M.B. 2005. Cellular integrity plus: Organelle-related and pro- tein-targeting functions of intermediate filaments. Trends Cell Biol. 15: 608-617.

Tong, X. and Coulombe, P.A. 2006. Keratin 17 regulates hair follicle cycling in a TNF $\alpha$-dependent fashion. Genes \& Dev. 20: $1353-1364$.

Traub, P., Bauer, C., Hartig, R., Grub, S., and Stahl, J. 1998 Colocalization of single ribosomes with intermediate filaments in puromycin-treated and serum-starved mouse embryo fibroblasts. Biol. Cell. 90: 319-337.

Tsuruta, D. and Jones, J.C. 2003. The vimentin cytoskeleton regulates focal contact size and adhesion of endothelial cells subjected to shear stress. J. Cell Sci. 116: 4977-4984.

Tzivion, G., Luo, Z.J., and Avruch, J. 2000. Calyculin A-induced vimentin phosphorylation sequesters 14-3-3 and displaces other 14-3-3 partners in vivo. J. Biol. Chem. 275: 2977229778.

Ueno, T., Toi, M., Biven, K., Bando, H., Ogawa, T., and Linder, S. 2003. Measurement of an apoptotic product in the sera of breast cancer patients. Eur. J. Cancer 39: 769-774.

Uttam, J., Hutton, E., Coulombe, P.A., Anton-Lamprecht, I., Yu, Q.C., Gedde-Dahl Jr., T., Fine, J.D., and Fuchs, E. 1996. The genetic basis of epidermolysis bullosa simplex with mottled pigmentation. Proc. Natl. Acad. Sci. 93: 9079-9084.

Uyama, N., Zhao, L., Van Rossen, E., Hirako, Y., Reynaert, H., Adams, D.H., Xue, Z., Li, Z., Robson, R., Pekny, M., et al. 2006. Hepatic stellate cells express synemin, a protein bridging intermediate filaments to focal adhesions. Gut 55: 1276 1289.

Vassar, R., Coulombe, P.A., Degenstein, L., Albers, K., and Fuchs, E. 1991. Mutant keratin expression in transgenic mice causes marked abnormalities resembling a human genetic skin disease. Cell 64: 365-380.

Venetianer, A., Schiller, D.L., Magin, T., and Franke, W.W 1983. Cessation of cytokeratin expression in a rat hepatoma cell line lacking differentiated functions. Nature 305: 730733.

Vicart, P., Caron, A., Guicheney, P., Li, Z., Prevost, M.C., Faure, A., Chateau, D., Chapon, F., Tome, F., Dupret, J.M., et al. 1998. A missense mutation in the $\alpha \mathrm{B}$-crystallin chaperone gene causes a desmin-related myopathy. Nat. Genet. 20: 92 95.

Vikstrom, K.L., Lim, S.S., Goldman, R.D., and Borisy, G.G. 1992. Steady state dynamics of intermediate filament networks. J. Cell Biol. 118: 121-129.

Wald, F.A., Oriolo, A.S., Casanova, M.L., and Salas, P.J. 2005. Intermediate filaments interact with dormant ezrin in intestinal epithelial cells. Mol. Biol. Cell 16: 4096-4107.

Watson, E.D., Geary-Joo, C., Hughes, M., and Cross, J.C. 2007. The Mrj co-chaperone mediates keratin turnover and prevents the formation of toxic inclusion bodies in trophoblast cells of the placenta. Development 134: 1809-1817.

Weisleder, N., Taffet, G.E., and Capetanaki, Y. 2004. Bcl-2 overexpression corrects mitochondrial defects and ameliorates inherited desmin null cardiomyopathy. Proc. Natl. Acad. Sci. 101: 769-774.

Werner, N.S., Windoffer, R., Strnad, P., Grund, C., Leube, R.E., and Magin, T.M. 2004. Epidermolysis bullosa simplex-type mutations alter the dynamics of the keratin cytoskeleton and reveal a contribution of actin to the transport of keratin subunits. Mol. Biol. Cell 15: 990-1002.

Wiche, G. 1998. Role of plectin in cytoskeleton organization and dynamics. J. Cell Sci. 111: 2477-2486.

Wilhelmsen, K., Litjens, S.H., Kuikman, I., Tshimbalanga, N., Janssen, H., van den Bout, I., Raymond, K., and Sonnenberg, A. 2005. Nesprin-3, a novel outer nuclear membrane protein associates with the cytoskeletal linker protein plectin. $J$. 
Cell Biol. 171: 799-810.

Windoffer, R., Woll, S., Strnad, P., and Leube, R.E. 2004. Identification of novel principles of keratin filament network turnover in living cells. Mol. Biol. Cell 15: 2436-2448.

Windoffer, R., Kolsch, A., Woll, S., and Leube, R.E. 2006. Focal adhesions are hotspots for keratin filament precursor formation. J. Cell Biol. 173: 341-348.

Wisniewski, T. and Goldman, J.E. 1998. $\alpha \mathrm{B}$-crystallin is associated with intermediate filaments in astrocytoma cells. Neurochem. Res. 23: 385-392.

Worman, H.J. and Courvalin, J.C. 2005. Nuclear envelope, nuclear lamina, and inherited disease. Int. Rev. Cytol. 246: 231-279.

Yan, Y. and Brown, A. 2005. Neurofilament polymer transport in axons. J. Neurosci. 25: 7014-7021.

Yang, X., Wang, J., Liu, C., Grizzle, W.E., Yu, S., Zhang, S., Barnes, S., Koopman, W.J., Mountz, J.D., Kimberly, R.P., et al. 2005. Cleavage of p53-vimentin complex enhances tumor necrosis factor-related apoptosis-inducing ligand-mediated apoptosis of rheumatoid arthritis synovial fibroblasts. Am. I. Pathol. 167: 705-719.

Yuan, A., Rao, M.V., Sasaki, T., Chen, Y., Kumar, A., Veeranna, Liem, R.K., Eyer, J., Peterson, A.C., Julien, J.P., et al. 2006. $\alpha$-Internexin is structurally and functionally associated with the neurofilament triplet proteins in the mature CNS. I. Neurosci. 26: 10006-10019.

Zatloukal, K., Stumptner, C., Fuchsbichler, A., Fickert, P., Lackner, C., Trauner, M., and Denk, H. 2004. The keratin cytoskeleton in liver diseases. J. Pathol. 204: 367-376.

Zimek, A. and Weber, K. 2005. Terrestrial vertebrates have two keratin gene clusters; striking differences in teleost fish. Eur. J. Cell Biol. 84: 623-635. 


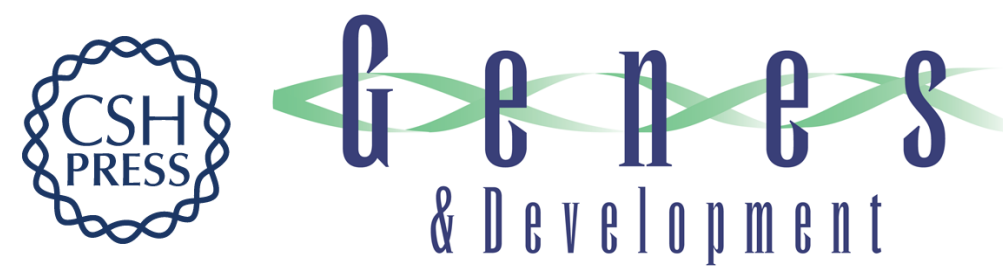

\section{Intermediate filament scaffolds fulfill mechanical, organizational, and signaling functions in the cytoplasm}

Seyun Kim and Pierre A. Coulombe

Genes Dev. 2007, 21:

Access the most recent version at doi:10.1101/gad.1552107

References This article cites 198 articles, 94 of which can be accessed free at: http://genesdev.cshlp.org/content/21/13/1581.full.html\#ref-list-1

License

Email Alerting

Receive free email alerts when new articles cite this article - sign up in the box at the top Service right corner of the article or click here.

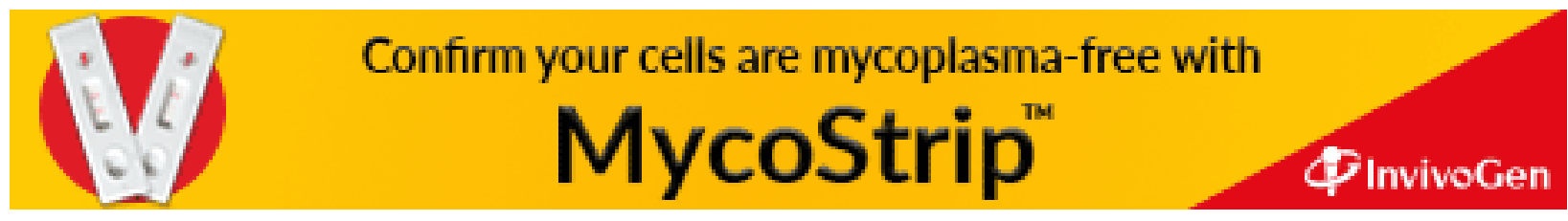

